\title{
ANITKABİR'DEKİ RENKLİ TAŞ SÜSLEMELER -İkonografik Bir Yaklaşım-
}

\author{
Alev ÇAKMAKOĞLU KURU*
}

\section{$\underline{\text { Özet }}$}

Türk mimarisinin Cumhuriyet Dönemi eserleri arasında Anıtkabir'in çok önemli bir yeri olduğu muhakkaktır. İkinci Ulusal Mimarlık Akımı'nın özelliklerini taşıyan bu yapı daha çok mimar kökenli araştırmacıların makaleleri ve kitaplarındaki bilgilerle tanımlanırken, Selçuklu ve Osmanlı Dönemi Türk eserlerine daha fazla ilgi gösteren sanat tarihçileri tarafından belki de değerlendirme sürecinin erken olabileceği endişesi ile ele alınmamıştır. Bu çalışmada yapı hakkında bilinenler özetlenerek, Anıtkabir'de kullanılan renkli taş süslemeler ve anlamları üzerinde durulmuştur.

Renkli taş süslemeler Anadolu Türk mimarisinde Selçuklu, Beylikler ve Osmanlı dönemlerinin farklı türdeki yapılarında yer almış, Cumhuriyet Dönemi'nde İkinci Ulusal Mimarlık Akımı'na ait yapılarda varlığını sürdürmeye devam etmiştir. Bu akımın önemli eseri olan Anıtkabir'in özellikle Şeref Salonu, Tören Alanı ve Atatürk'ün Mezar Odası'nda yer alan renkli taş süslemeler Türk sanatının Orta Asya kaynaklı motiflerini yaşatmaktadır. Bu motifler süslemenin yanı sıra taşıdıkları anlamları ile de Türk mitolojisinden izlere sahiptir.

Anahtar Kelimeler: Anıtkabir, süsleme, ikonografi, renkli taş, Emin Onat, Orhan Arda.

$$
\text { 2๐ล }
$$

\section{COLOURED STONE DECORATIONS IN ANITKABIIR -An Iconographic Approach-}

\begin{abstract}
$\underline{\text { Abstract }}$
It is certain that Anttkabir has a very important place among the works of the Turkish Architecture in the Republican Era. This structure, which carries the characteristics of the Second National Architecture trend, has been defined more often with the information in the articles and books of the architecture originated researchers, while it has not been dealt with by the art historians who are more interested in the Turkish works of the Seljuki and Ottoman periods based on the worry that the assessment value might be early. In this paper, an attempt has been made to summarize what is already known about the structure and focus has been given on the coloured stone decorations used in Anttkabir and on their meanings.

The colored stone decorations took place in various buildings of Seljuks, Beyliks and Ottoman Periods in Anatolian Turkish Architecture and continued to exist in buildings belonging to the Second National Architecture Movement during the Republican Period. The colored stone decorations of Anttkabir, especially the Hall of Honor, the Ceremony Hall and Atatürk's Grave Room, which are the most important works of this movement, are the motifs of Turkish Art originating from Central Asia. These motifs have traces of Turkish Mythology as well as their decoration and meaning.
\end{abstract}

Keywords: Anttkabir, Decoration, Iconography, Coloured stone, Emin Onat, Orhan Arda.

\footnotetext{
* Prof. Dr., Gazi Üniversitesi, Gazi Eğitim Fakültesi, Ankara. E-mail: alevkuru@gazi.edu.tr
} 


\section{Giriş}

Henüz on beşinci yılını idrak eden genç Türkiye Cumhuriyeti'nin kurucusu, ilk Cumhurbaşkanı Mustafa Kemal Atatürk'ün 10 Kasım 1938 tarihinde vefatının ve 19 Kasım günü İstanbul'dan yola çıkan cenazenin 20 Kasım'da Ankara'da, Etnografya Müzesi'nde geçici olarak hazırlanan yerine tahnit edilerek konulmasının ardından Atatürk'ün mezar anıtı olabilecek yer arayışlarına başlanmıştır. Bu amaçla Başbakanlık müsteşarının başkanlığında özel bir komisyon kurulmuş, komisyonun 17 Ocak 1939 tarihindeki son toplantısından, Anıtkabir için Rasat Tepe kararı ile birlikte bir de proje yarışması fikri çıkmıştır. ${ }^{1}$ Yarışma sonucunda seçilen üç eser arasından 7 Mayıs 1942 tarihinde hükümet, Prof. Dr. Emin Onat ve Doç. Dr. Orhan Arda'ya ait projenin uygulanması yönünde karar aldığını açıklamıştır. Bu seçimin gerçekleşmesinde en önemli faktörün, Türk mimarlara ait eserin, anıta esas teşkil eden "Milli Konu"yu daha başarılı ifade etmiş olmasından kaynaklandığı yönündedir. ${ }^{2}$

Bölgedeki kamulaştırma çalışmalarından sonra Anıtkabir inşaatı 2. Dünya Savaşı'nın gölgesinde, 9 Ekim 1944 tarihinde yapılan temel atma töreni ile başlamış, 1953 yilında tamamlanmıştır.

Onat ve Arda'nın projelerinde üçüncü düzeltme esas alınarak başlanan Anıtkabir'in inşası, 9 yıllık bir süre içinde dört aşamalı olarak Anıt Bloku ve Barış Parkı olarak iki kısımda yapılmıştır. Anıt Bloku, Aslanlı Yol, Tören Alanı ve Mozole bölümlerinden oluşmakta; Barış Parkı'nda ise Türkiye'nin çeşitli bölgelerinden ve yabancı ülkelerden getirilen fidanlarla 104 ayrı türden yaklaşık 48.500 adet süs ağacı ve süs bitkisi bulunmaktadır. ${ }^{3}$

1 Atatürk gömüleceği yer konusunda bir vasiyette bulunmamıştı. Prof. Dr. Afet İnan 1923 yılında, bir sohbet sırasında, Atatürk'ün “Elbet bir gün öleceğim, beni Çankaya'ya gömer, hatıramı yaşatırsınız." dediğini; ve ardından, bunda ısrarlı olmadığını belirtmek için de "Beni milletim nereye isterse oraya gömsün. Fakat benim hatıralarımın yaşayacă̆ y yer Çankaya olacaktır." şeklinde konuştuğunu belirtmektedir. (İnan, 1972, 43-57.)

2 Şapolyo, 1972, 112.

3 Anıtkabir yapımında Birinci Kısım İnşaat (1944-1945), toprak seviyesi ve Aslanlı Yol'un istinat duvarının yapılmasını kapsamaktadır. İkinci Kısım İnşaat (1945-1950), Mozole ve Tören Alanı'nı çevreleyen yardımcı binaların yapılmasını kapsamaktadır. Üçüncü Kısım İnşaat (1950), Anıt'a çıkan yollar, Aslanlı Yol, Tören Alanı ve Mozole üst döşemesinin taş kaplaması, merdiven basamaklarının yapılması, lahit taşının yerine konması ve tesisat işlerinin yapılmasını kapsamaktadır. Dördüncü Kısım İnşaat (1950-1953) ise, Şeref Salonu'nun döşemesi, tonozlar alt döşemeleri ve Şeref Salonu çevresi taş profilleri ile saçak süslemelerinin yapılmasını kapsamaktadır. (Arda 1961-62, 155; Evliyagil, 1947.)

Yaklaşık $750.000 \mathrm{~m}^{2}$ 'lik bir yerleşme alanına sahip Anıtkabir'in çevresine ilişkin peyzaj planlamasına 1946 yılında başlanmıştır. Prof. Dr. Paul Bonatz'ın önderliğinde Prof. Dr. Emin Onat ve Prof. Dr. Sadri Aran'ın görüşleri doğrultusunda, çevre düzenlemesine ilişkin uygulama projeleri Prof. Sadri Aran tarafından hazırlanmıştır. 
Anıtkabir'e asıl yönelme, Tandoğan tarafındaki girişten sonra yer alan kuzeybatı-güneydoğu yönünde Tören Alanı'na kadar uzanan yol ile gerçekleşmektedir. Yirmi altı basamaklı merdivenle çıkılan yolun başlangıcında kareye yakın dikdörtgen planlı Hürriyet ve İstiklal Kuleleri yer almaktadır. Hürriyet Kulesi'nin önünde Hüseyin Özkan tarafından yapılan erkekler grubu, İstiklal Kulesi'nin önünde ise kadınlar grubu heykelleri görülmektedir. Her iki tarafı güller ve ardıçlarla süslü yol traverten döşelidir. Yolun her iki tarafında olmak üzere ikişerli gruplar halinde yine Hüseyin Özkan'ın yaptığı 24 adet aslan heykeli bulunmaktadır. Bu heykellerin 24 Oğuz Boyunu temsil ettiği de ifade edilmektedir. Aslanlı yol, Mehmetçik ve Müdafa-i Hukuk Kuleleri ile Tören Alanına açılmaktadır. Uzunlamasına dikdörtgen, 15.000 kişi kapasiteli Tören Alanı'na, dört tarafından üçer basamak merdivenle inilmektedir. (Şek. 1, Fot. 1)
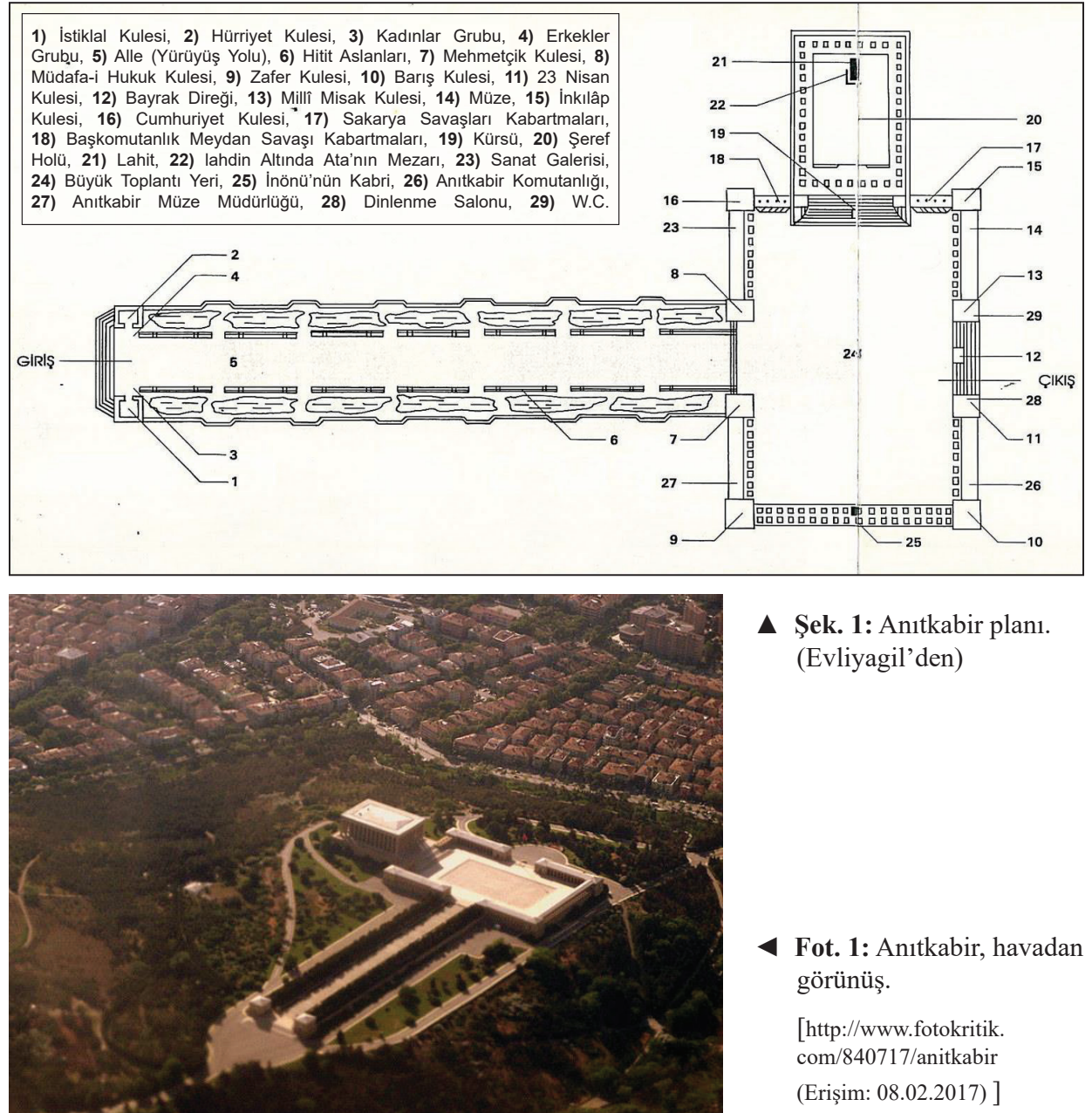

A Şek. 1: Anıtkabir planı. (Evliyagil'den)

Fot. 1: Anttkabir, havadan görünüş.

[http://www.fotokritik com/840717/anitkabir (Erişim: 08.02.2017) ] 
Her bir köşesine, kareye yakın dikdörtgen formlu, üzeri içte aynalı tonoz, dışta -tepelerinde alem olan- piramit çatı ile örtülü kuleler yerleştirilen alanı, üç yönden revaklar çevrelemektedir. (Fot. 2) Barış, 23 Nisan, Milli Misak, İnkılâp, Cumhuriyet Kulelerinin dışında, revaklara, ayrıca Komutanlık, Kütüphane, Müze Müdürlüğü gibi işlevleri olan mekânlar da açılmaktadır. Bu mekânların duvarları dikdörtgen pencereleri ve kapılarının üst kısımlarında sathı basık kemerlerle hareketlendirilmiştir. (Fot. 3) Ayrıca revakların ve Mozole'nin tonoz örtülü galerilere sahip zemin katı dikdörtgen şeklinde küçük pencereler ile dışarıya açılmaktadır. Anıtkabir yapı topluluğu içerisinde, simetrik olarak yerleştirilmiş on adet kulenin ve revakların tavanlarında, fresk tekniğinde, Türk kilimlerinden alınmış geometrik motifler görülmektedir. ${ }^{4}$ Tören Alanı, Mozole merdivenlerine, üzerinde Zühtü Müridoğlu'nun eseri Başkomutanlık Meydan Savaşı ve İlhan Koman'ın eseri Sakarya Savaşı kabartmalarının yer aldığı duvar kütlesi ile bağlanmaktadır. Aslanlı Yol ile aynı eksende bulunan 23 Nisan ve Milli Misak kuleleri arasında Anıtkabir'in Çankaya yönündeki merdivenlerinin ortasında, tek parça çelikten imal edilmiş yüksek bir direk üzerinde Türk Bayrağı dalgalanmaktadır. ${ }^{5}$

Tören Alanı’ndan, üzerinde Atatürk'ün “Hâkimiyet kayıtsız şartsız milletindir.” sözleri yazılı olan, Kenan Yontuç’un eseri Hitabet Kürsüsü’nün de bulunduğu 42 basamaklı merdivenle Mozole'ye çıkılmaktadır. Anıtkabir'in en önemli bölümünü teşkil eden Zemin+bir katlı ve dikdörtgen planlı Mozole, Atatürk'ün kabrini ve sembolik lahdinin bulunduğu Şeref Salonu'nu ihtiva etmektedir. Zemin katın dış duvarlarının kesik piramit biçiminde, masif bir kitle halinde olması yapının alt kesiminde bir kale görünüşü kazanmasına sebep olmuş, yapıda yükseklik etkisini artırmıştır. ${ }^{6}$ Anıtkabir'in diğer kısımlarında olduğu gibi burada da üzerinde küçük pencereler bulunan dış duvarlar, beton üzerine traverten ile kaplanmıştır.

Asıl ziyaret mekânını oluşturan Şeref Salonu'nu dışarıdan traverten taş kaplamalı beton kolonları ile bir revak çevrelemektedir. Ön ve arka cephede ortadaki iki kolon arasındaki açıklık diğerlerine göre daha geniş tutularak mozolenin basık kemerli mermer söveli ana girişi ve aynı eksende yer alan Atatürk'ün lahdi vurgulanmıştır. Mozole cephesinin solunda Atatürk'ün Türk Gençliğine Hitabl, sağda ise 10. Yll Nutku taş kabartma üzerine altın yaldız harflerle Emin Barın tarafından yazılmışlardır. Bronz kapılardan girilen Şeref Salonu'na ortadaki daha geniş, yanlardaki daha dar açıklığa sahip iki sıra kolon dizisinin meydana getirdiği hazırlık mekânı ile geçilmektedir. Zemin ve duvarları mermer döşeli olan Şeref Salonu'nda girişin tam karşısında bronz şebekeli Ankara Kalesi manzaralı büyük pencerenin yer aldığı, eyvan olarak nitelenebilecek derinlikteki niş içerisinde Atatürk'ün sembolik lahdi yer almaktadır. Özellikle X. yüzyıldan itibaren

4 Gülekli, 1973, 41.

5 Bu bayrak direğini, Amerika'da yerleşmiş olan Nazmi Cemal adında bir Türk vatandaş1 göndermiştir. Çelikten tek parça olarak imal edilen Bayrak direği 4938 kilogram ağırlı̆̆ında ve 33.528 m yüksekliğindedir. Dört metresi kaidenin altında olup, görünen kısm1 29.528 m'dir.

6 Aslanoğlu, 2000, 276. 


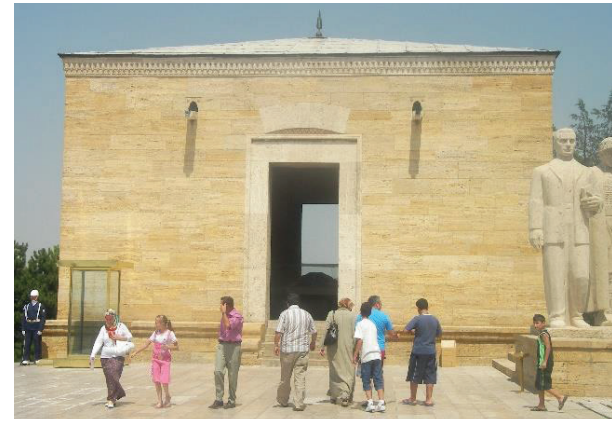

Fot. 2: Hürriyet Kulesi.

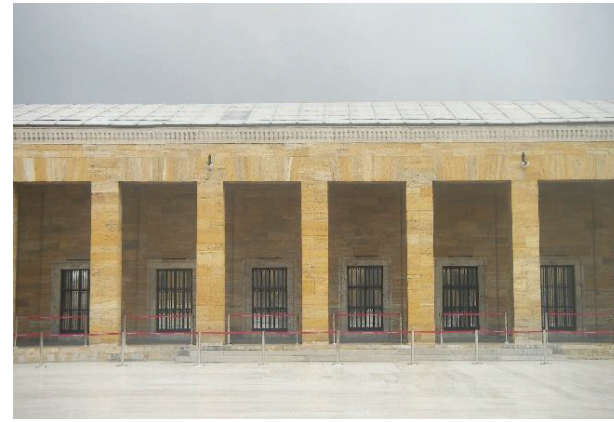

Fot. 3: Revaklar.

Türk Mimarisinin yoğun olarak kullandığı eyvanları hatırlatan nişin Şeref Salonu'nun zemininden yüksek olması ve bu nişte yer alan bronz şebekeli pencereden süzülen 1 şı dikkatleri öncelikle lahit üzerinde toplamaktadır. Şeref Salonu'nun zemini ve duvarları Türkiye'nin çeşitli illerinden çıkarılan mermerlerle kaplanmıştır. Şeref Salonu'nun iki yan bölümünde dikdörtgen planlı galeriler yer almaktadır. Zemini mermer olan galeriler 9'ar adet çapraz tonozla örtülüdür. Şeref Salonu'nun 27 kirişten oluşan tavanı ile galeri tavanları mozaik ile süslenmiştir. Şeref Salonu'nda kapı ve pencerelerin yonca motifli şebekelerinin dışında, yan duvarlarındaki altışardan 12 adet meşalesinde de bronz kullanılmıştır. Mozole'nin üstü ise düz kurşun çatı ile örtülüdür.

Mozolenin zemin katında ise üzeri çapraz tonozlarla örtülü koridorlara, beşik tonoz tavana sahip eyvan şeklindeki mekânlar açılmaktadır. Atatürk'ün aziz naaşı, bu katta doğrudan doğruya toprağa kazılmış sekizgen bir mezar odasında bulunmaktadır. Mozole'nin birinci katı olan şeref salonundaki sembolik lahit taşının tam altında bulunan mezar odası tepesi sekizgen 1şıklıkla kesilmiş bir piramidal külahla örtülüdür. (Fot. 4) Mezar odasında zeminin ortasında kıble yönündeki lahit sekizgen alanla sınırlandırılmıştır. Mermer sandukanın çevresine, bütün illerden, Kıbrıs'tan, Azerbaycan'dan gönderilen toprakların konulduğu pirinç vazolar bulunmaktadır. ${ }^{7}$ Zemin ve duvarları mermerlerle kaplanan mezar odasının mozaik tekniğindeki yeşil örtüsü, ortadaki sekizgen 1şıklıktan yayılan altın renginde sekiz adet 1şık huzmesine sahiptir. Aslında biçim olarak çok farklı bir etki bıraksa da Anıtkabir üst kat ziyaret yeri alt kat asıl mezar odası yerleşimi ile Anadolu Selçuklu döneminin kümbet mezar anlayışını fikir olarak yaşatmaktadir.

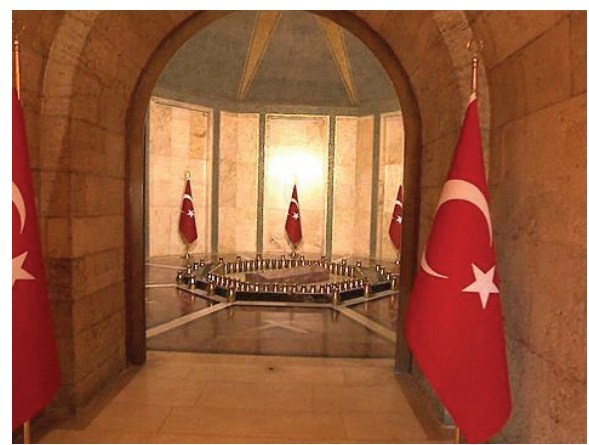

Fot. 4: Atatürk'ün mezar odası.

7 Evliyagil 1988, 87. 


\section{Anıtkabir'deki Renkli Taş Süslemeler}

Türk Sanatından alıntıların yoğunlaştığı fark edilen Anıtkabir'deki süslemelerin dördüncü kısım inşaatı sırasında yani 1950-1953 yılları arasında gerçekleştiği muhakkaktır. II. Dünya Savaşı sonrası, Anıtkabir inşaatının asıl süslemelerinin, ince işleri ile projeye uygun bir şekilde tamamlandığ 1 dönemdir. ${ }^{8}$

Yapı kabaca ortaya çıkmış, sıra süslemelerine gelmiştir. Türkiye'de o döneme kadar mozaik süsleme uygulaması yapılmadığından bahisle Anıtkabir'in mozaikleri için çeşitli ülkelerle yazışmalar gerçekleştiğinden söz edilmektedir. Yapı ve İmar İşleri Reisliği’nin, Almanya Büyükelçiliği’ne 5 Ekim 1951 tarihli yazısı, mozaikte uzman büyük firma isimleri istenmesi ile ilgilidir. Sonunda Anıtkabir'deki mozaik süslemeleri bir İtalyan firması olan Marmi üstlenmiştir.' Firma yetkilileri 30 Ocak 1952'de Bayındırlık Bakanlığı'na gönderdikleri yazıda tarihe mal olmuş büyük şahsiyetlerin eserlerinin altın ve smalt mozaikle olmayıp, tamamen altın ve renkli altın mozaikle yapıldığından bahisle, Anıtkabir'de de altın ve altın renkli mozaik kullanılmasını tavsiye etmişlerdir. ${ }^{10}$

İtalyan Marmi Firması, Anıtkabir'deki işlerini uygulamaya 22 Temmuz 1952 'de başlayarak sekizgen mezar odasını, lahdin bulunduğu nişin tavanını ve Şeref Salonu'nun tavanındaki kirişleri, Şeref Salonu'nun giriş tavanını, galerileri örten çapraz tonozları altın, kırmızı ve yeşil smalt mozaiklerin çeşitli tonlarıyla kaplamıştır. ${ }^{11}$ Ayrıca kulelerin kapı ve pencere üstündeki basık kemerli alınlıklarında da mozaik kullanılmıştır. Mozaikler için motifler, İstanbul Türk ve İslam Eserleri Müzesi'ndeki XV ve XVI. yy.

8 Bunun için Başbakanlık’taki Anıtkabir Komisyonu'na bağlı olarak yeni bir komisyonun daha kurulduğu anlaşılmaktadır. Yapı ve İmar İşleri Başkanı Selahattin Onat, Türk Tarih Kurumu'ndan Prof. Dr. Halil Demircioğlu, Ankara Üniversitesi'nden Prof. Dr. Ekrem Akurgal, proje mimarlarından Doç. Orhan Arda ve Anıtkabir inşaatı Kontrol Şefi Yüksek Mimar Sabiha Güreyman' dan oluşan bu ikinci komisyonun görevi, Anitkabir'de yapılması düşünülen heykel ve kabartmaların konuları ile anıtın çeşitli yerlerine yazılacak yazıların tespit edilmesiydi. 3 Mayıs 1950 tarihindeki toplantıda konunun önemine bağlı olarak kendilerinin yetersiz kalabilecekleri endişesiyle komisyonu genişletme kararı aldılar. (T.C. Genel Kurmay Başkanlığı, 2001, Belge 29.) Bayındırlık Bakanlığı'ndaki 31 Ağustos 1951 tarihindeki toplantıya yukarıdakilere ilave olarak Prof. Dr. Ahmet Hamdi Tanpınar, Prof. Dr. Rudolf Belling, Prof. A. Afetinan, Prof. Enver Ziya Karal, Doç. Kemali Söylemezoğlu, Prof. Emin Barın, Milli Eğitim Bakanlığı temsilcisi Kamil Su, Faik Reşit Unat ve Enver Behnan Şapolyo, Bayındırlık Bakanlığı temsilcisi Müsteşar Muammer Çavuşoğlu katılarak Anıtkabir'e yazılacak yazılar ve yapılacak heykel ve kabartmalar için de birer alt komisyon kuruldu. Aynı zamanda Anıtkabir'deki on kulenin isimlerini de veren heykel ve kabartmaların konularını tespit için oluşturulan komisyonda Prof. Ahmet Hamdi Tanpınar, Prof. Ekrem Akurgal, Prof. Belling, Doç. K. Söylemezoğlu yer almaktadır ve değişmez şekilde bu komisyon toplantılarına, Anıtkabir'in mimarları da katılacaklardır. (T.C. Genel Kurmay Başkanlığı, 2001, Belge 30.)

9 T.C. Genel Kurmay Başkanlığı, 2001, 61, Belge 55.

10 T.C. Genel Kurmay Başkanlığı, 2001, Belge 56.

11 Yapı ve İmar İşleri Reisliğinin 14 Ekim 1953 tarih Anıtkabir 33542/89 sayılı yazısı. 
kilim ve halılarından Emin Onat ve Orhan Arda tarafından seçilmiş ve bu motiflerin 11 tanesi birleştirilmek suretiyle bir kompozisyon oluşturulmuştur. ${ }^{12}$ Yine İ.T.Ü. öğretim üyelerinden Nezih Eldem, eğitim amacıyla bulunduğu İtalya'da (1952-53) kaldığı iki yıl boyunca aynı zamanda Anıtkabir'in bu ülkede üretilen mozaik bezemelerinin ve tunç parmaklıklarının tasarım ve denetleme sorumluluğunu da üstlenmiştir. Anıtkabir'deki mozaik süslemelerde Türk Sanatına ait motiflerin kullanmasının yanında tıpkı Bizans mozaiklerinde olduğu gibi altına da yer verilmiştir. Renkli taş ve çini mozaik tekniği ile Türk Sanatında önemli eserlerin varlığı bilinmekle birlikte; tercih, Türk Sanatında gördüğümüz, yüzyıllardır bilinen, sevilerek uygulanan örneklerden değil de, bu tekniğin yabancı bir çeşitlemesi ile gerçekleşmiştir. ${ }^{13}$ Onat ve Arda'nın denetimleri ve seçimleri doğrultusunda Türk halı ve kilimlerinden alınmış motifler, mozaikler dışında Mozole'yi ve avluyu çevreleyen revakların, kulelerin tavanlarındaki kalem işlerinde de kullanılmıştır. $\mathrm{Bu}$ freskler ise Tarık Levendoğlu tarafindan yapılmıştır.

Anıtkabir'de çoğu zaman detay olarak geçilen, bazen de gözlerden uzak yerlerde dikkatlerden kaçan renkli taş ${ }^{14}$ süslemeler ise Türk sanatının üzerinde durulması gereken örnekleri olarak karşımıza çıkmaktadır. Betonarme iskelet olan yapının dış malzemesinde sarı traverten taş kaplamasıyla klasik bir etki verildiği muhakkaktır. ${ }^{15}$ Emin Onat ve Paul Bonatz'ın Antik yapılardaki gibi Anıtkabir'de de dayanıklı-kalıcı malzeme olarak traverten kullanımını uygun gördükleri belirtilmektedir. ${ }^{16}$ Taş, sadece Antik yapılarda değil Anadolu Selçuklu ve Osmanlı mimarilerinde de asıl malzeme olarak yüzyıllar boyunca kullanılmıştır.

Anıtkabir'in inşaatında kullanılan travertenler, Ankara'nın Haymana, Malıköy, Papazderesi; Çankırı'nın Eskipazar ve Kayseri’nin Pınarbaşı yörelerinden; mermerler ise Afyon, Çanakkale, Bilecik, Adana ve Hatay illerinden getirilmiştir. Getirilen taşların kesilmesi için, o zaman inşaatı süren 3. T.B.M.M. binasındaki (1938-1963) atölyenin düşünüldüğü belirtilmektedir. ${ }^{17}$ Eskipazar'dan getirilen travertenlerin ${ }^{18}$ delikli gözenekli olması sorun çıkarmış olmalı ki taşlar hakkında Yapı ve İmar İşleri Reisliği’nin 11 Şubat 1949'da Bakanlığa sunduğu yazıda yapısı gereği delikli olan bu taşların kullanımı ile ilgili zorluklara değinilerek tekrar görüss istenmektedir. ${ }^{19}$ Buradan yerli malzemeye yer verilen binada imkânlar ölçüsünde titiz davranıldığı da anlaşılmaktadır. Çankırı - Eskipazar'dan

12 T.C. Genel Kurmay Başkanlığ1, 2001, 61.

13 Yetkin 1972,153-159, Çakmakoğlu 1983, 1-12

14 Taş geniş bir kavram olarak mermer malzemeyi de kapsamaktadır. 05.06.2004 tarih ve 25483 say1lı Resmi Gazete'de yayımlanan Maden Kanunu'nda mermer; "II. Grup madenler; Dekoratif taşlar, Traverten, Kalker, Dolomit, Kalsit, Granit, Siyenit, Andezit, Bazalt ve benzeri taşlar" kapsamındadır.

15 Aslanoğlu, 2000, 276.

16 Aslanoğlu, 1994, 230.

17 Alpagut, 1999, 52.

18 Erdoğdu, 1999, 281.

19 T.C. Genel Kurmay Başkanlı̆̆ 
getirilen sarı travertenler Şeref Salonu'na çıkan merdivenlerin sağında ve solundaki kabartmalarda, Şeref Salonu'nun dış duvarlarında, Tören Alanı'nı çevreleyen revaklarda kullanılmış, ${ }^{20}$ Kayseri'den getirilen beyaz travertenlere merdivenlerde, Aslanlı Yol ile Tören Alanı döşemelerinde ve Mozole kolonatları üzerindeki lentolarda yer verilmiştir. ${ }^{21}$ Ayrıca, Kayseri - Boğazköprü'den getirilen kırmızı, Kumarlı Mevkii’nden getirilen siyah travertenler ise Toplantı Alanı ve Kulelerin zemin döşemelerinde kullanılmıştır. ${ }^{22}$ Kuleleri, Revaklı Avlu'yu, Şeref Salonu'nun cephelerini ve kolonları kaplayan sarı renkli travertenler ile bütün yapıları saçak altında dolaşan beyaz renkli mukarnas etkili korniş ve çörtenlerle iki renklilik oluşturulmaktadır. Ayrıca kapı ve pencereleri çevreleyen beyaz taş söveler ve bunların üstündeki mozaik alınlıkların yine beyaz renkli basık kemerleri Anıtkabir yapı topluluğuna ağırbaşılı bir renklilik kazandırmaktadır. Aslanlı Yol'un, merdivenlerin, Mozole'nin kolonlarının üstündeki lentoların taşlarında beyaz rengin varlığı cephe kaplamalarında kullanılan sarı renk ile denge yaratmaktadır. İstiklal, Hürriyet ve Zafer Kulelerinin içlerinde ise traverten taşların derz aralarında zemine paralel halde ve pencere çerçevelerinin kenarlarında turkuaz renkte çiniler, yine Türk Mimarisinde özellikle Selçuklu Dönemi tuğla yapılarını hatırlatmaktadır. ${ }^{23}$

Tören Alanı'nda beyaz taşların oluşturduğu zeminde küp şeklindeki kırmızı ve siyah taşlarla kilim desenleri meydana getirilmiştir. Tören Alanı'nın tam ortasında siyah taşlarla sınırlanmış büyük bir kilim görüntüsünde bir kompozisyon yer almaktadır. Göbekteki kırmızı ve siyah taşların meydana getirdiği eşkenar dörtgen şeklindeki motifi, siyah taşlarla "yaba" ya da "ok yay” denilen motiflerin kırmızı taşlarla çevrelenerek geniş kenar suyunun uzun kenarlarına dizildiği görülmektedir. Kısa kenarlarında yarım eşkenar dörtgenlere sahip olan aynı kenarsuyun zeminini çapraz denilen motifler tek veya ikişerli olarak doldurmaktadır. (Fot. 5) Bunun dışında, Tören Alanı siyah taşlarla çevrelenen yine kırmızı ve siyah taşların kullanıldığı daha küçük boyutta dikdörtgen bölümlere ayrılmıştır. Bu dikdörtgen alanların hepsinde, göbek kısmında tam, kenarların ortasında ise yarım eşkenar dörtgen şeklinde birer motif bulunmaktadır. (Fot. 6) Ortadaki siyah taşları çevreleyen kırmızı taşlardan oluşan tam eşkenar dörtgenden çıkan kırmızı şeritler, köşegenler oluşturmaktadır. Bu arada Tören Alanı'nı sınırlayan revak zeminlerinde sarı travertenlerle çevrelenmiş siyah taşların meydana getirdiği dörtgen bölümler, atlamalı olarak yer almaktadır. (Fot. 7) Tören Alanı'nın uzun kenarlarındaki revaklarda bu

20 İkinci kısım inşaatın yüklenici firması Rar-Türk Limited Sosyetesi’ne sarı travertenleri Eskipazar'a yakın Budaklar köyü civarındaki taş ocaklarından çıkartmak için 2 Eylül 1944 de yazı gönderildi. (T.C. Genel Kurmay Başkanlığı, 2001, 37.)

21 Mozole kolonları üzerine yapılacak lentolar hakkında düzenlenen 14.8.1951 tarihli raporda "Renk itibariyle Eskipazar travertenine yakın renkte, daha mütecanis sert ve sağlam olan Kayseri taşı ile lentoların yapılması daha muvafik olacaktır. Zaten basamaklarla basamak önü döşemesi ve bilimum basamaklarla alan ve meydan kaplaması da Kayseri taşı ile yapılmaktadır." denilmektedir. (T.C. Genel Kurmay Başkanlığ 1 , 2001, Belge 18, Belge 37.)

22 T.C. Genel Kurmay Başkanlığı, 2001, Belge 36, Belge 15.

23 Tekin, 2005, 72-73. 


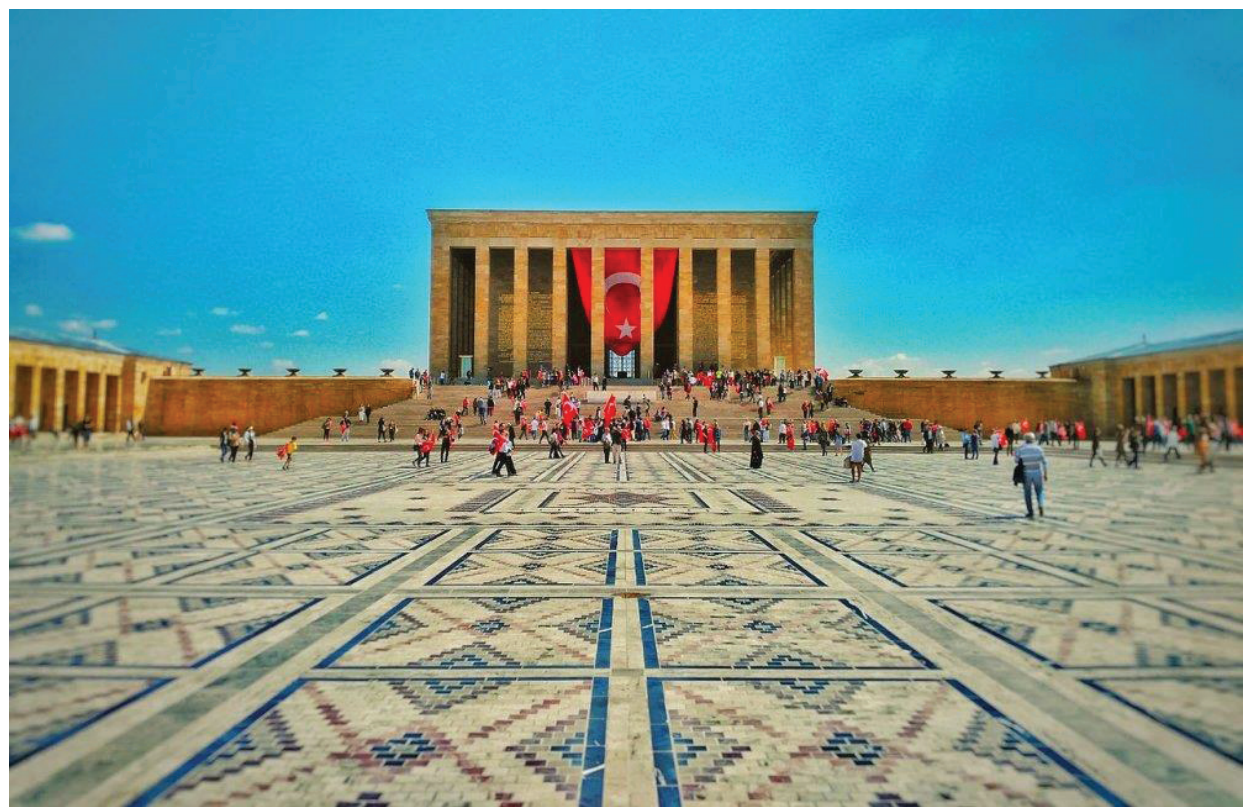

Fot. 5: Tören Alanı'ndaki renkli taş süslemelerden.
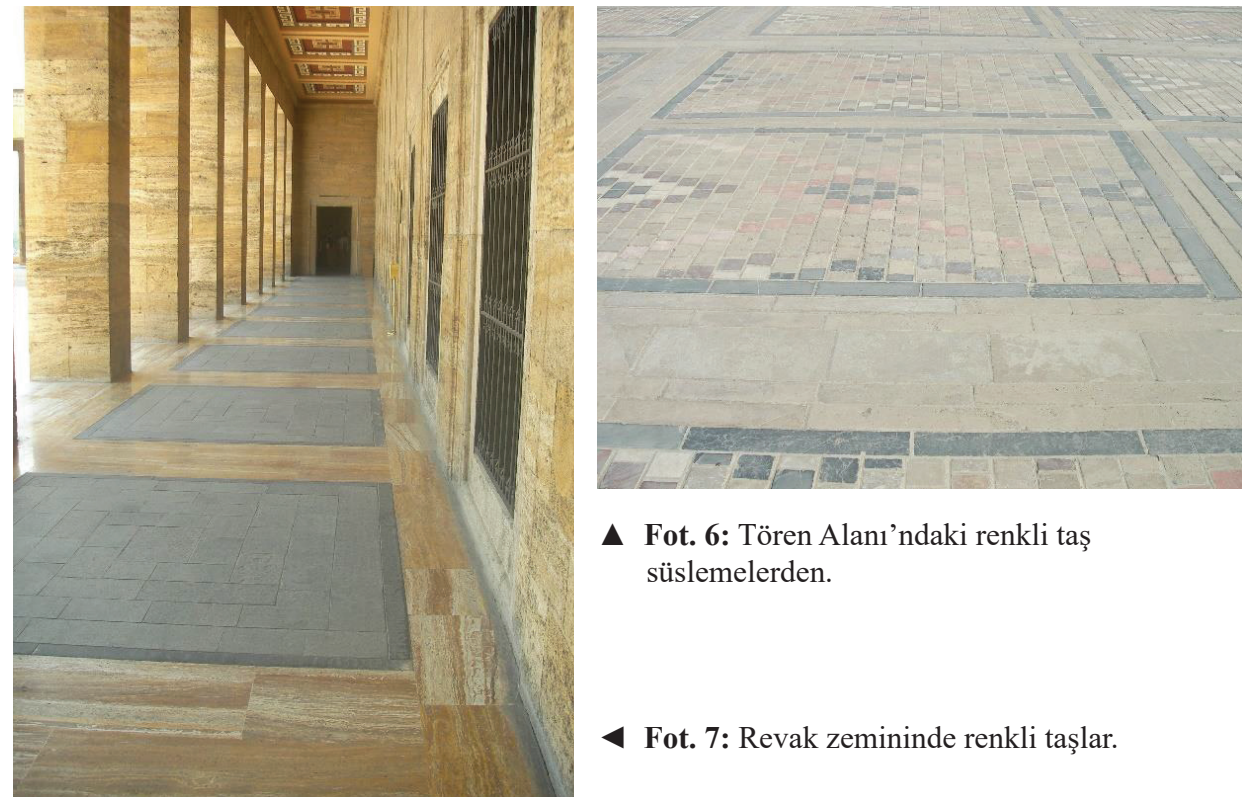

A Fot. 6: Tören Alanı'ndaki renkli taş süslemelerden.

Fot. 7: Revak zemininde renkli taşlar. 
dörtgenlerin her biri, revaka açılan pencere veya kapı hizasında; çift kolonatlı kısmında ise her bir kolon çiftinin arasındaki zeminde yer almaktadır.

Ayrıca renkli taşlar kulelerin zeminlerinde de görülmektedir. İstiklal ve Hürriyet Kulelerinin kırmızı taş zeminlerinde sarı renkli taş şeritler alanı dikdörtgenlere bölmektedir. Misak-1 Milli, 23 Nisan, Müdafaa-i Hukuk ve Mehmetçik Kulelerinin kırmızı taş zemininde köşelerden çıkan diyagonal siyah şeritler merkezde iki çapraz meydana getirmektedir. İnkılap Kulesi'nin kırmızı zemininin ortasında dikdörtgen alan, kısa kenarlarda siyah, uzun kenarlarda kırmızı taşla çevrelenmiş, mekânın kenarları siyah taş şeridin meydana getirdiği tarak motifi ile sınırlanmıştır. Cumhuriyet Kulesi'nin kırmızı taş zeminlerinde ortadaki dikdörtgen siyah bölümü siyah renkli şeritler bir kilim motifi oluşturacak şekilde çevrelemektedir. Zafer ve Barış Kulelerinde yine kırmızı zeminin ortasında, siyah şeritlerle çevrelenmiş dikdörtgen alanda, şeritler köşegen yaparak merkezde kesişmektedir. Dikdörtgenin böylece meydana getirilen her üçgen alanına siyah renkli birer üçgen yerleştirilmiştir. Ayrıca dikdörtgenin her kenarında, sırtı dönük "M" harfine benzer bir motif görülmektedir.

Kap1 ve pencere sövelerinde, kolonların lentolarında, saçak altında kornişte beyaz taşın yer aldığı sarı traverten kaplamalı cepheleri ile Mozole; içerde renkli mermerin zengin kullanımına sahiptir. Şeref Salonu'nun zemini Çanakkale'den getirilen krem, Hatay'dan getirilen kırmızı ve Adana'dan getirilen siyah renkte mermer ile döşenmiştir. Afyon'un kaplan postu, beyaz mermeri ile Bilecik'in yeşil renkteki mermeri Şeref Salonu'nun iç-yan duvarlarını kaplamıştır. ${ }^{24}$ Şeref Salonu'na açılan eyvanın duvarları ve zemini beyaz Afyon mermeri ile kaplanmış eyvana konulan lahit için Osmaniye'nin Gavur Dağları'ndan kesilen, 40 ton ağırlığındaki iki adet yekpare kırmızı mermer Ankara'ya getirilerek Kayserili Hacı Mustafa Kuranel'in taş ocağında işlenmiştir. ${ }^{25}$

Mozole'yi çevreleyen revakın beyaz mermer zemininde her kolon çiftinin oluşturduğu aralığa denk gelecek şekilde kırmızı renkte mermer şeritlerin çevrelediği beyaz dörtgen alanlara yer verilmiştir. (Fot. 8) Beyaz ve krem renkte mermerlerle döşenmiş Şeref Salonu'na giriş ya da hazırlık kısmında eşiklerin ardından siyahla çevrelenen enine dikdörtgen kırmızı mermerler yerleştirilerek her üç giriş noktası adeta işaretlenmiştir. (Fot. 9) Şeref Holü'nün daha geniş olan orta girişinde, hazırlık mekânının ortasında kırmızı ve siyah renkte mermerlerden Türk halı ve kilimlerinde sıkça görülen stilize edilmiş koçboynuzu motifleri, uzunlamasına dikdörtgen şeklindeki alanın dört yönüne yerleştirilmiştir. (Fot. 10) Daha dar olan iki yan girişte, zeminin ortasında uzunlamasına dikdörtgen alanlarda siyah mermer üzerine kırmızı mermerle stilize edilmiş koçboynuzları dikkat çekmektedir. Şeref holünde zemini, yan kenarlarda, zemindeki siyah mermerin belirginleştirdiği kırmızı mermerin oluşturduğu şeritten çıkan kırmızı dişlerden bir kenarsuyu sınırlamaktadır. (Fot. 11) Türk halı ve kilimlerinde çokça

24 Anıtkabir inşası için istenen yeşil taşın Bilecik'e bağlı Hasandere köyü civarından olduğu, 12.8.1949 tarihli belgeden anlaşılmaktadır.

25 T.C. Genel Kurmay Başkanlığı, 2001, 37, Belge 19; Gülekli, 1973, 78. 


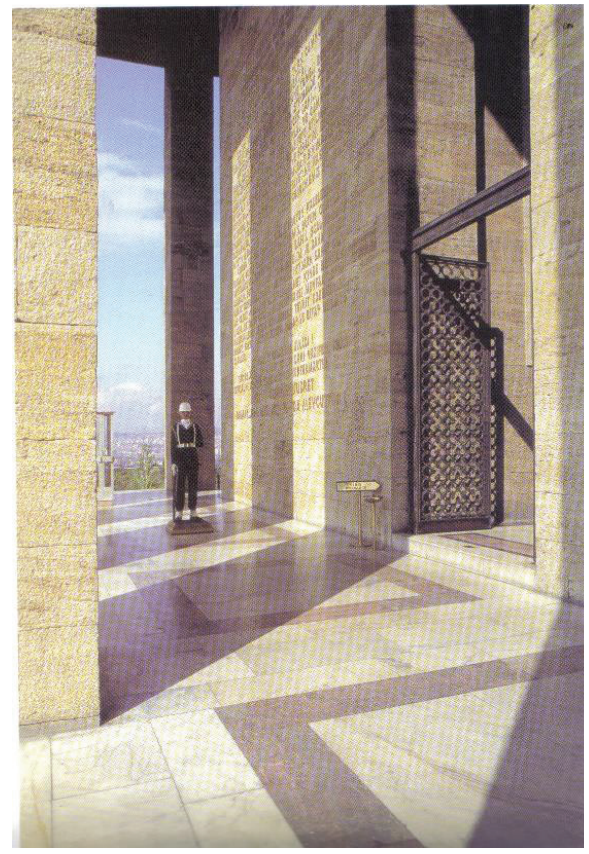

Fot. 8: Mozole'nin revak zemini. (Sağdıç’tan)

V Fot. 9: Şeref Holü'ne giriş.
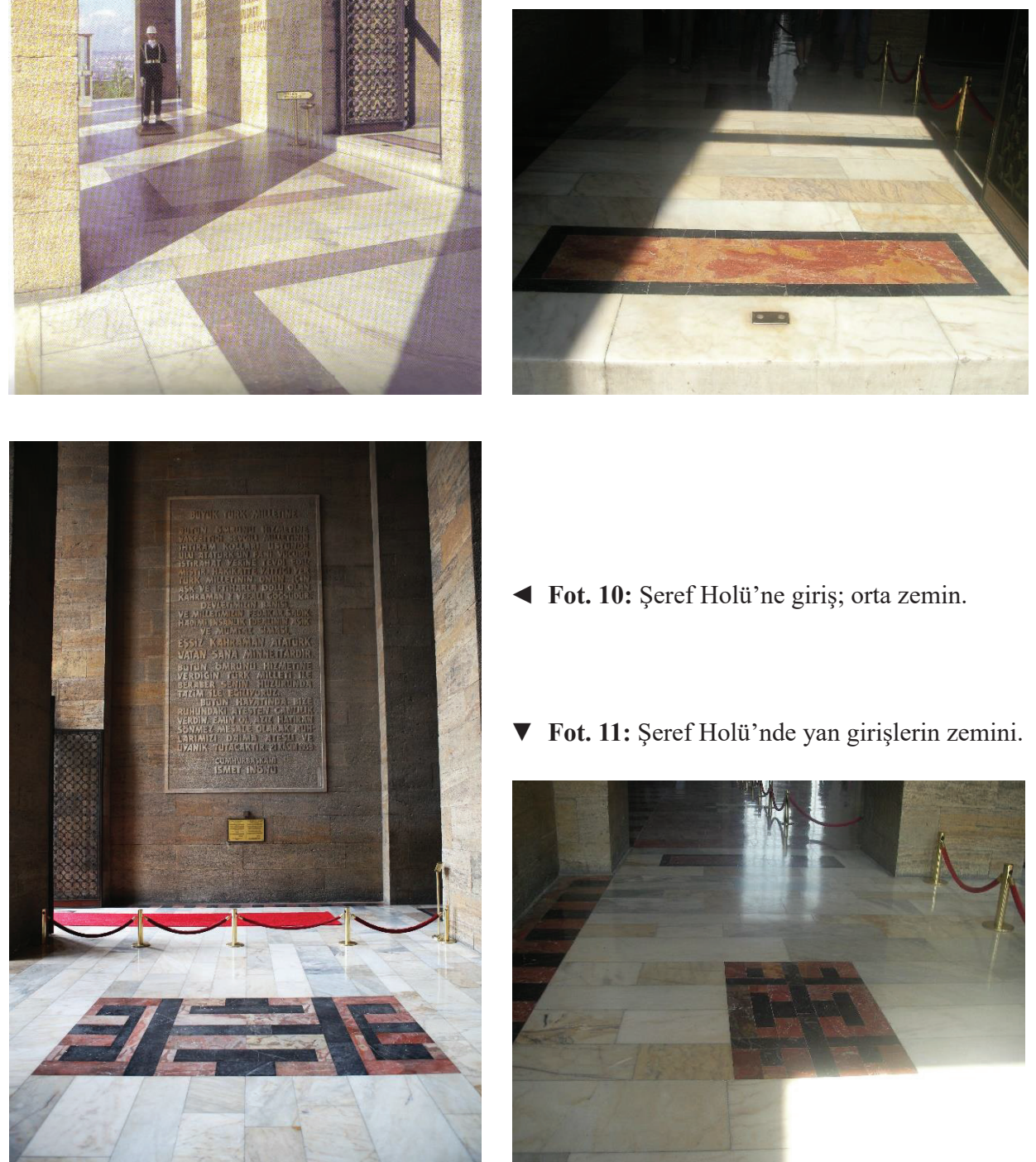

4 Fot. 10: Şeref Holü'ne giriş; orta zemin.

V Fot. 11: Şeref Holü'nde yan girişlerin zemini.

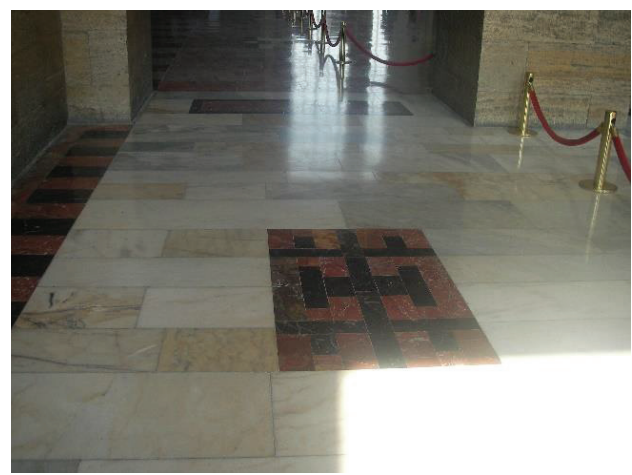


kullanılan, genelde tarak motifi denilen bu kenarsuyunun varlığı bu manada kullanılan diğer motiflerle birlikte Şeref Salonu'nun zemininin büyük bir halı ile kaplı olduğu izlenimini vermektedir. Hazırlık mekânını Şeref Salonu'na bağlayan kolonların arasında kalan zemin bölümleri, ortadaki daha geniş, yanlardaki daha dar ve giriştekilerin aynısı olmak üzere siyahla çevrelenmiş kırmızı enine dikdörtgenlere sahiptir.

Döşemesi kırmızı granit olan dikdörtgen planlı Şeref Salonu'nun ${ }^{26}$ uzun kenarlarında, hazırlık mekânındaki tarak motifli kenarsuyun daha geniş bir şekilde bu defa kırmızı zemin üzerine siyah dişlerle devamı görülmektedir. (Fot. 12) $\mathrm{Bu}$ kenarsuyun dişında, atlamalı olarak siyah, beyaz mermerlerin oluşturduğu dar bir yol Şeref Salonu'nun uzun kenarlarını sınırlamaktadır. Taraklı geniş kenarsuyunun dışında, ortası sade bırakılan Salon döşemesinin kenarlarında, hazırlık mekânında yan girişlerin zemininde bahsettiğimiz koçboynuzlu alanların hizasında olmak kaydı ile belli aralıklarla beşer adet uzunlamasına dikdörtgen bölümler yerleştirilmiştir. Siyah zemine sahip bu alanlarda beyaz mermer ile "yaba" da denilen "ok ve yay" motifleri, yine, Türk sanatında çok kullanılan bir deseni oluşturmaktadır. (Fot. 13)

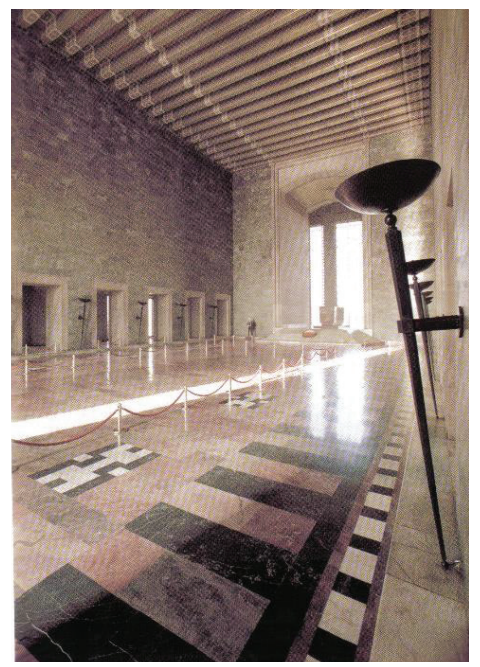

Fot. 12: Şeref Salonu. (Sağdıç’tan)

$\nabla$ Fot. 13: Şeref Salonu'nda ok-yay motifleri.

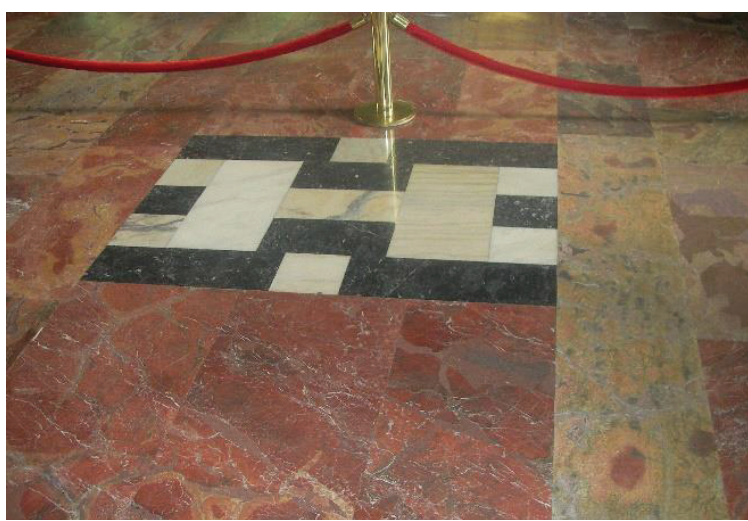

Şeref Salonu'nun uzun kenarlarındaki galerilere geçiş sağlayan mermer söveli yedi açıklığın aralarında kalan zeminler ise ortadaki dikdörtgen biçimli beyaz mermeri çevreleyen bej renkli mermer şeridin kısa kenarlarda stilize koçboynuzları şeklinde kıvrılması ile bezenmişlerdir. (Fot. 14) Aynı şekilde süslemeler galeri pencerelerinin zeminlerinde de görülmekte, üzeri mozaik süslü tonozlarla örtülü her iki galerinin dokuz bölümünde de zeminler aynı anlayış ile ama motiflerin farklı düzenlemeleri ile karşımıza çıkmaktadır. Şeref Salonu'nun sol yan galerisinde girişten itibaren birinci bölümdeki kare

26 T.C. Genel Kurmay Başkanlığı, 2001, Belge 14. 
alanın dört köşesinde siyah mermer şeritler atlamalı olarak ortalarındaki enine ve uzunlamasına dikdörtgen şeklindeki beyaz mermer alanları çevrelemektedir. (Fot. 15) Aynı galerinin ikinci bölümünde, merkezdeki enine dikdörtgen alanı çevreleyen siyah mermer şeritler uzun kenarlara doğru köşeli olarak kıvrılarak yine koçboynuzlarını meydana getirmektedir. Üçüncü bölümde siyah şeritlerin yine dar ve geniş olarak kullanılmasıyla koçboynuzu motiflerinden bir kompozisyon elde edilmiştir. (Fot. 16) Galerinin dördüncü bölümünde siyah mermer şeritlerden dikdörtgenin kısa kenarlarına soyutlanmış, parçalanarak yerleştirilmiş koçboynuzu motiflerinin izlerini görmekteyiz. (Fot. 17) Galerinin beşinci bölümünde siyah ve beyaz renkteki mermerler dama taşına benzer bir kompozisyonla karşımıza çıkmaktadır. Dikdörtgenin her iki kısa kenarında ortadaki uzunlamasına dikdörtgene üstte ve altta köşelerden birleşen dört dikdörtgen bize özellikle kilim ve halılarda görülen bazı Türk boylarına ait damgaları da hatırlatmaktadır. ${ }^{27}$ Altıncı bölümde dikdörtgenin uzun kenarlarının ortasındaki uzunlamasına dikdörtgen alanları çevreleyen siyah şeritler, kısa kenarlarda kıvrılarak stilize koçboynuzlarına dönüşmektedir. (Fot. 18) Galerinin yedinci bölümünün zemininde dikdörtgen alanın kısa kenarlarına yerleştirilen siyah mermer şeritlerin oluşturduğu ok-yay ya da yaba denilen motiflerden bir kompozisyon yer almaktadır. (Fot. 19) Sekizinci bölümde ortada uzunlamasına dikdörtgen alanı sınırlayan siyah şeritler kısa ve uzun kenarları devam ettirerek kenarların üstünde dört yönde bir çift koçboynuzu oluşturmaktadırlar. Ayrıca dörtgenin köşelerine yerleştirilen L şeklindeki siyah mermerler kompozisyonu tamamlamaktadır. Soldaki galerinin dokuzuncu bölümünde, bir öncekini hatırlatır biçimde gayet soyut geometrik bir düzenleme bulunmaktadır. Burada, ortadaki dikdörtgenden çıkan şeritler dört yönde farklı olarak dikdörtgen alanlar meydana getirecek şekilde kapanmaktadır. (Fot. 20)

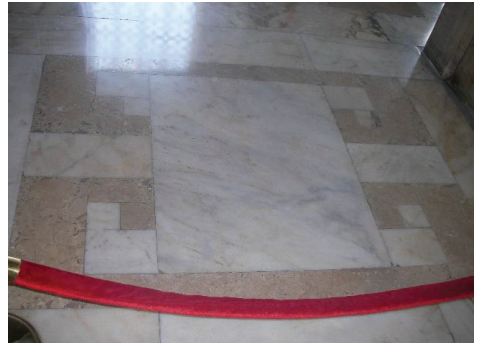

Fot. 14: Galerilerde açıklıkların zemini.

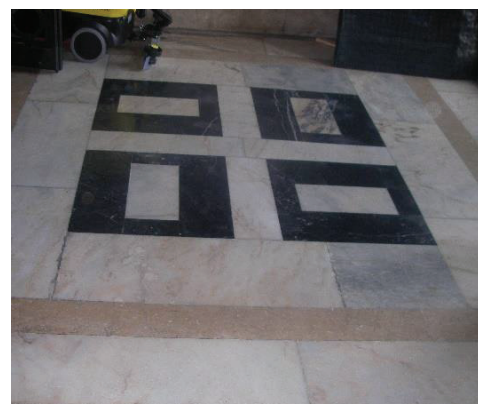

Fot. 15: Soldaki galerinin 1. bölüm zemini.

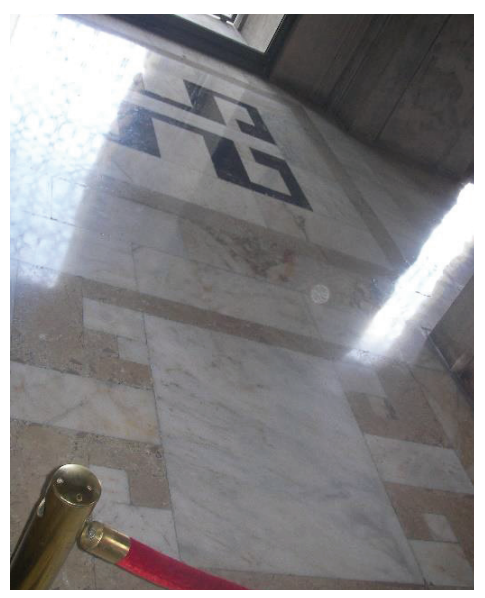

Fot. 16: Soldaki galerinin 3. bölüm zemini. 


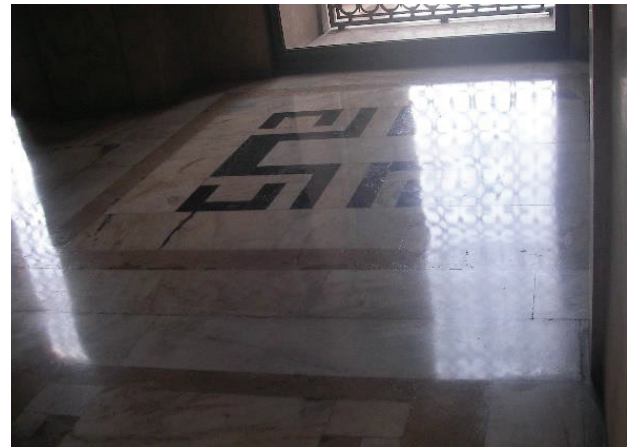

Fot. 17: Soldaki galerinin 4. bölüm zemini.

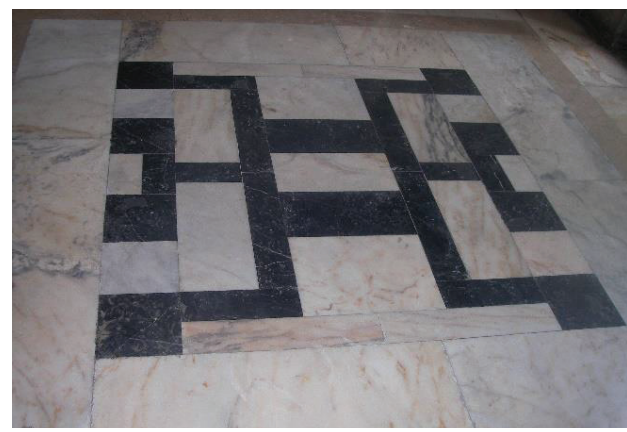

Fot. 19: Soldaki galerinin 7. bölüm zemini.

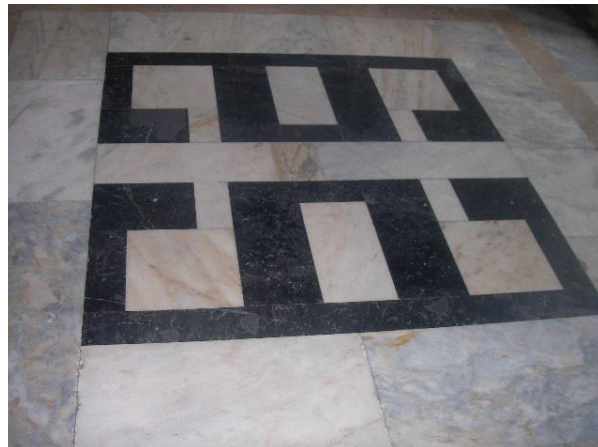

Fot. 18: Soldaki galerinin 6. bölüm zemini.

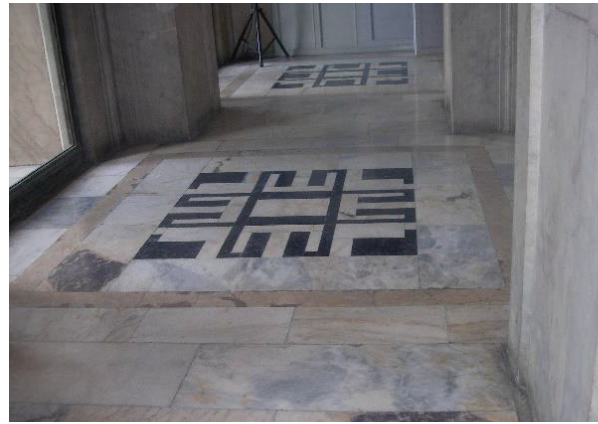

Fot. 20: Soldaki galerinin 8 ve 9. bölüm zemini.

Aynı şekilde düzenlenen Şeref Salonu'nun sağdaki galerisinin zemininde, giriş tarafından birinci bölümde ortadaki dikdörtgeni çevreleyen siyah şeritlerin stilize edilmiş iki çift koçboynuzuna dönüştügü fark edilmektedir. (Fot. 21) Galerinin ikinci bölümünün zemininde uzun kenarlara yerleştirilen, siyah şeridin meydana getirdiği, birbirine sırtları dönük koçboynuzları, ortada dikine atılan bir şeritle birbirine bağlanmaktadır. (Fot. 22) Üçüncü bölümün zemininde, yine siyah mermer şeritler ortadaki kareyi altta ve üstte takip ederek uzun kenarlarda koçboynuzu oluşturmaktadırlar. (Fot. 23) Dördüncü bölümde, bu defa ortasında kare şeklinde beyaz mermer olan enine dikdörtgenin köşelerinden çıkan şeritler koçboynuzlarını meydana getirmektedir. (Fot. 24) Beşinci bölümün zemininde kare alanın dört köşesinin her birinde siyah mermerle ok-yay motifleri işlenmiştir. (Fot. 25) Bu motif Türk halı ve kilimlerinde de kendini göstermektedir. ${ }^{28}$ Galerinin altıncı bölümünün zemininde, kare alanın kenarlarında, siyah renkli mermer şeritler simetrik olarak birer koçboynuzu oluşturmaktadır. (Fot. 26) Yedinci bölümün zemininde yine siyah mermer şeritler ok-yay motifleri ile bir kompozisyon meydana getirmektedir. (Fot. 27) Galerinin sekizinci bölümünün zemininde karenin alt ve üstündeki koçboynuzları yine siyah mermer

28 Azak, 1993,168. 
şeritlerle birleştirilerek farklı bir düzenleme elde edilmiştir. Galerinin dokuzuncu bölümünde kare alana alt ve üstte yatay olarak yerleştirilen, yine siyah mermer şeritlerin meydana getirdiği koçboynuzu motifleri yer almaktadır. (Fot. 28)

Şeref Salonu'nun altındaki zemin katın, günümüzde müze olarak değerlendirilen tonozlu mekanları ile koridorlarının zeminlerinde de renkli mermer kullanımı söz konusudur. Beyaz mermer döşemeli koridorları, nişleri de dâhil olmak üzere, kenarlarda bej renkli mermerden ince bir şerit sınırlamakta, aynı renkteki şerit belli aralıklarla kare alanları da dolaşarak koridor boyunca ilerlemektedir. Koridorlara açılan tonozlu mekânların zemininde ise niş kısmına doğru girinti yapan bej renkli şeritler dikdörtgen birer alan meydana getirmektedir. $\mathrm{Bu}$ dikdörtgen alanlarda daha küçük kesilmiş mermerler dekoratif bir şekilde düzenlenmiştir. (Fot. 29) Tonozlu koridorlardan geçilerek ulaşılan üst kattaki lahdin tam altına gelen mezar odasında da mermer süslemelere rastlanmaktadır. Mezar odasında; yeşil mozaikle kaplı sekizgen kubbenin oturduğu -yine yeşil mozaikli- sekizgen kasnaktan çıkan altın yaldızlı ince şeritlerle sınırlanmış kenar suları, mezarın sekizgen duvarlarının her birini, ortadaki daha geniş olmak üzere, bej renkli mermerle kaplı üç bölüme ayırmaktadır. Mezar odasında, sekizgen zeminin ortasındaki beyaz mermer alanda kıble yönünde kırmızı mermer lahit yer almakta, sekizgen alanı bir basamak teşkil edecek yükseltide siyah mermer sinırlamaktadır. (Fot. 30) Mezar odasının zeminindeki sekizgen alanı ve buradan duvarlara doğru genişleyen sekiz adet dörtgen bölümü, beyaz mermerden ince bir kenarsuyu çevrelemektedir. Siyah ince şeritlerin kuşattığı yamuk dörtgen biçimli bu alanlarda kırmızı zemin üzerinde beyaz çarpı şeklindeki motiflere yer verilmiştir. Çarpıların veya çapraz denilen motiflerin üst ve alt açıklıkları siyah üçgenlerle dolgulanmıştır.

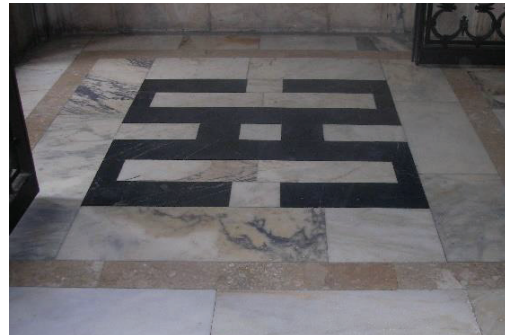

Fot. 21: Sağdaki galerinin 1. bölüm zemini.

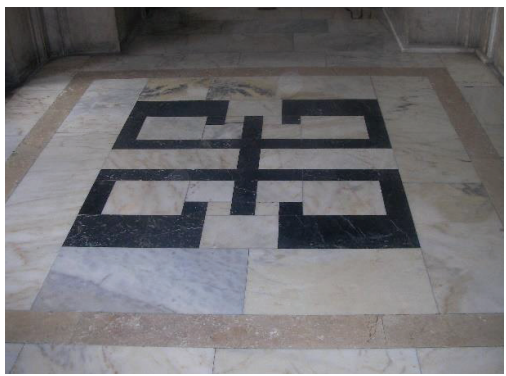

Fot. 22: Sağdaki galerinin 2. bölüm zemini.

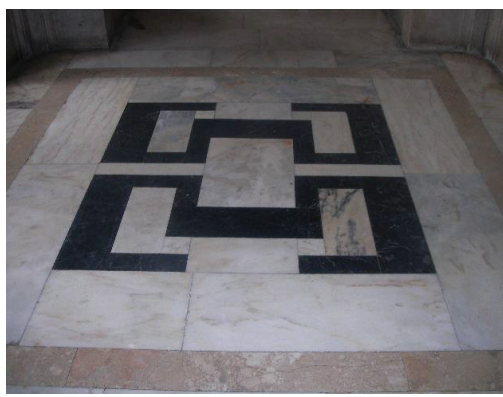

Fot. 23: Sağdaki galerinin 3. bölüm zemini.

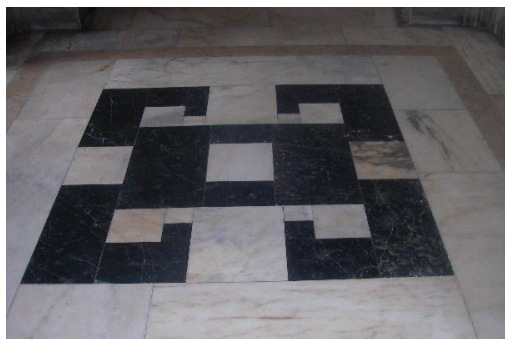

Fot. 24: Sağdaki galerinin 4. bölüm zemini. 


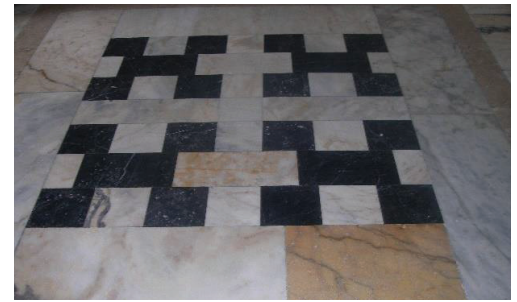

Fot. 25: Sağdaki galerinin 5. bölüm zemini.

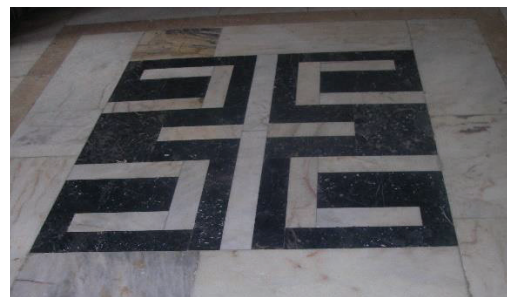

Fot. 26: Sağdaki galerinin 6. bölüm zemini.

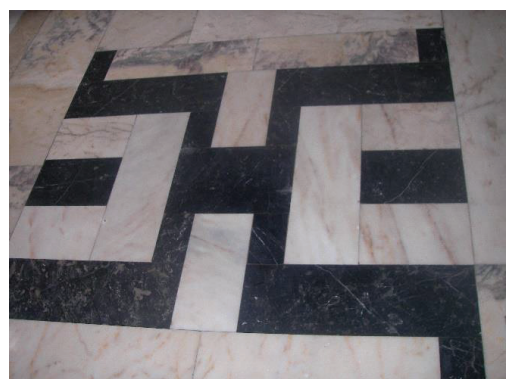

Fot. 27: Sağdaki galerinin 7. bölüm zemini.

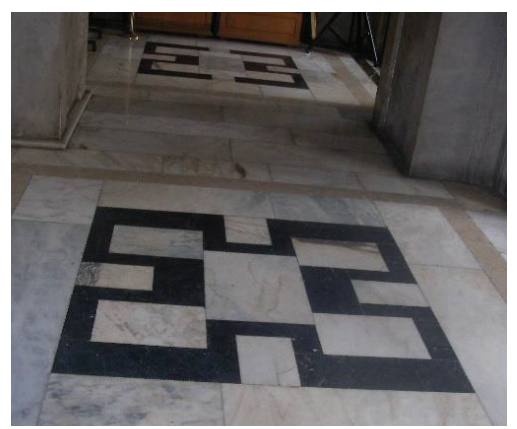

Fot. 28: Sağdaki galerinin 8 ve 9 . bölüm zemini.
Anıtkabir'in, araştırmacıların pek de ilgisini çekmemiş olan renkli taş kullanımı, görüldüğü üzere Anıtkabir yapılar topluluğunda gerek cephelerde gerekse zemin döşemelerinde abartılı olmayan bir yoğunlukta karşımıza çıkmaktadır. 2. Ulusal Mimarlık Akımı'nın özelliklerini taşıdığ 1 belirtilen Anıtkabir ile çağdaş yapılarda da, Anıtkabir kadar özenli olmamakla birlikte, renkli taş ya da mermer kullanımına özellikle kamu yapılarının girişlerinde, zeminlerde olmak üzere yer verilmiştir. ${ }^{29}$ Bunlar içinde, Anıtkabir Şeref Salonu'ndaki renkli mermer kullanımı ve motifler ile 3. Meclis Binası'nın Şeref Holü'ndeki renkli taş zemin süslemeleri birbirlerine benzer özellikler taşımaktadırlar.

Her ne kadar Türk mimarisinde renkli taş kullanımının başlangıçta daha çok IrakSuriye etkili olduğu bilinse de, minareler dişında renkli taşların cephelerdeki kullanımı ilk defa I. Alâeddin Keykubad zamanında Selçuklu başkenti Konya'da gerçekleşmiştir. ${ }^{30}$ Taşın yoğun olarak kullanıldığı Anadolu Selçuklu mimarisinde mermer malzeme, bazı yapıların taçkapılarında muhteşem örneklerle karşımıza çıkarken; kitabe, mezar taşı, sanduka, ${ }^{31}$ pencere söve ve alınlıklarında, havuz ve fiskiyelerde kullanıldığ $1,{ }^{32}$ sütun başlıklarında ise çoğunlukla devşirme malzemeye yer verildiği bilinmektedir. ${ }^{33}$ XIV. yy. Beylikler Dönemi mimarisinde mermer, dönem özelliği olarak, taçkapılar dışında binaların bütün cephelerini kaplamaktadır. ${ }^{34}$ Mermer süslemeler, ya da renkli taş süslemeler asıl, Osmanlı mimarisinde, özellikle Klasik Dönem'de ölçülü bir şekilde yapılardaki yerini almıştır. Mermer, başta girişlerde olmak üzere 1. Ulusal Mimarlık

29 Aslanoğlu, 2000, 274.

30 Eser, 2000, 126, 165.

31 Karamağaralı, 1992, 2.

32 Önge, 1997.

33 Öney, 1970, 27-38.

34 Diez vd., 1950, 195-197. 
Dönemi yapılarında da yoğun olarak kullanım alanı bulmuştur. ${ }^{35}$ Böylece Türk mimarlık tarihinde her iki "Ulusal Mimarlı Akımı"nın Osmanlı Klasik Dönem - Mimar Sinan yapıları ile ilişkilerinin yeniden altı çizilmektedir. ${ }^{36}$

Türk sanatında yapıların taçkapılarında, pencere söve ve alınlıklarında, sütunlarda, mihrap ve minberlerin yanı sıra döşemelerde, duvar kaplamalarında, merdiven basamakları ve korkuluklarda, çeşmeler, sebil-

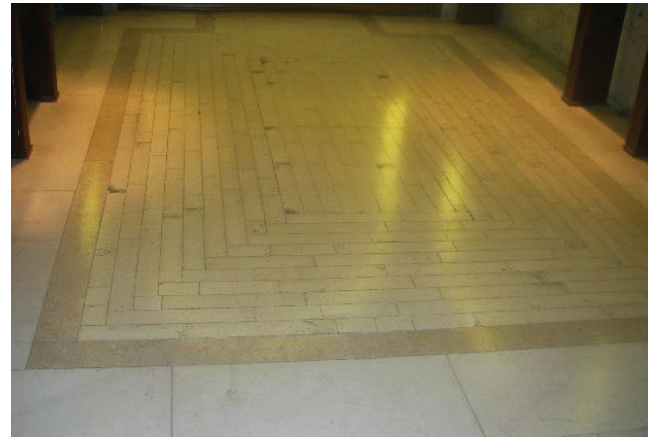

Fot. 29: Tonozlu mekanlarda zemin. ler ve mezar taşlarında kullanılan mermer süslemelerin muhteşem örnekleri Osmanlı Klasik Mimarisi'ne aittir. ${ }^{37}$ Osmanlı mimarisinde pencere nişlerinde, revak, avlu ve iç mekân döșemelerinde görülen renkli taş süslemelerin Anıtkabir'e ait revak, avlu ve Şeref Salonu'nun zemininde döşeme olarak varlığını sürdürdüğü anlaşılmaktadır. ${ }^{38}$ Anıtkabir'deki süslemeler içinde en dikkat çekeni de Şeref Salonu'nun zemininde bir bakıma mozaik tekniğinde sayılabilecek mermer kaplamalardaki motiflerdir. Genel olarak Anıtkabir ile ilgili kitap, makale ve internet bilgilerinde Şeref Salonu ile ilgili olarak "yan galerileri ve zemini, XV.-XVI. yüzyll hall ve kilimleri üzerine araştırma yapan I.T.Ü. ögretim üyelerinden Nezih Eldem 'in (2005) tasarladı̆̆ motiflerden oluşan renkli mozaiklerle süslüdür." șeklinde anlatımlarla karșılaşılmakta, hatta bazı araștırmacılar Anıtkabir'deki tüm bezeme ve tasarımların Nezih Eldem tarafından gerçekleştirildiği üzerinde durmaktadırlar. ${ }^{39} 1999$ yılında aramızdan ayrilan Prof. Dr. Orhan Arda'nın kendisi gibi mimar olan oğlu Sn. Ömer Arda ile yapılan görüşmeden, Prof. Dr. Nezih Eldem'in İtalya'da bulunduğu dönemde sadece, Anıtkabir için üretilen mozaiklerin kontrolörlüğünü yaptığı, Türk İslam Eserleri Müzesi'nde tesbit edilen motiflerde ise tercihin Anıtkabir mimarlarına ait olduğu anlaşılmıştır.

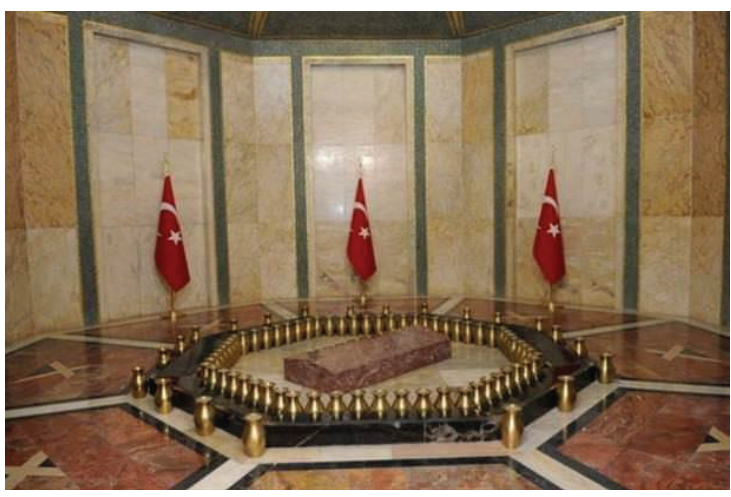

Fot. 30: Atatürk'ün mezarı.

35 Yavi, 1996, 22.

36 Sözen, 1984, 30.

37 Çakmakoğlu, 1983, 1-12.

38 Çakmakoğlu, 1989, 33.

39 Batur, 2001, 12. 


\section{Anıtkabir'deki Renkli Taş Süslemelere İkonografik Bir Yaklaşım}

Araştırmalarımız sırasında dikkatimizi çeken bir başka unsur da özellikle Şeref Salonu ve Atatürk'ün Mezar Odası'nda mermer süslemelerde kullanılan renklerin, motiflerin sadece biçim yönü ile değil taşıdıkları anlamlardan dolayı da seçilmiş olabilecekleriydi. Şeref Salonu ve salon döşemesindeki motiflerin içinde yer aldığı alanların dörtgen şekli, Türklerin dünyayı bir tepsi gibi, kubbeli bir tepsi gibi düşündüklerini, Türk devletini dört köşe olarak algıladıklarını hatırlatmaktadır. ${ }^{40}$

Anıtkabir'de biçimlerin yanı sıra bazı renklerin de özellikle tercih konusu olduğu düşünülmektedir. Şeref Salonu'nun zemininde, lahitte, Mezar Odası'ndaki mermer sandukada ve Mezar Odası'nın zemininde, merkezdeki sekizgen alanı çevreleyen kısımda kırmızı rengin varlığı söz konusudur. Kırmızının genel olarak güc, kuvvet, iktidar, şiddet ve yoğunluğu ifade ettiği, savaşın ve zaferin rengi olduğu, aynı zamanda güneyi de temsil ettiği bilinmektedir. ${ }^{41}$ Yine Şeref Salonu'nda Atatürk'ün lahdinin bulunduğu eyvan, zeminden başlayarak tavana kadar; ve Mezar Odası'nda kırmızı lahdin bulunduğu sekizgen bölümün zemini beyaz renkte mermerle kaplanmışlardır. Her şeyden önce masumiyet, temizlik anlamına gelen beyaz, kutsallığ $l$ da sembolize ederken diğer taraftan devletin adalet ve gücünü de temsil etmektedir. Ayrıca beyaz rengin ölüm ya da ölümden duyulan üzüntüyü ifade etmesinin dışında, "ak" sözcüğünün Altay Türkçesinde cennet anlamına geldiği, cennette oturan tanrılarına $A k l 1 l a r$ denildiği belirtilmektedir. ${ }^{42}$ Esas taraf kabul edilen batının sembolü olmasının dışında, Hz. Muhammed'in kullandığ 1 üç sancaktan birinin rengi olmasıyla beyazın anlamı İslamî açıdan da yücelmekte; beyaz, ölümle tekrar doğmaya özgü bir geçiş rengi olarak kabul edilmektedir. ${ }^{43}$ Bir taraftan da, Atatürk'ün beyaz mermer döşeme üzerinde yer alan kırmızı mermer lahdinin ve sandukasının varlı̆̆ Türk Bayrağı'nı ve bu Bayrağın temsil ettiği Türk Milleti'ni hatırlatmakta; Atatürk'ün, Türk Milleti’nin sînesinde yattığını sembolize etmektedir.

Şeref Salonu'nun duvarlarını kaplayan yeşil mermerin ise, gelen ışıkla gök rengine doğru değiştiği fark edilmektedir. Gök ve yerin birbirini bütünlemesi gibi yeşil ve mavi de birbirini bütünlemektedir. Daha çok yer kavramı için kullanılan yeşil, Türklerde hükümdarlık ve hâkimiyet ile ilgili olarak, gençliğe, umuda, yeniden doğuşa, cennete, peygamber sülalesine işaret edebilmektedir. ${ }^{44}$ Ruhun ve düşüncenin rengi olan ve daha çok gök için kullanılan mavi ise ciddiyet ve asaletin varlığ 1 ile sonsuz bir yolun rengidir. ${ }^{45}$ Türk dünyasında yeşil ya da gök rengi aynı zamanda doğuyu da ifade etmektedir.

\footnotetext{
40 Ögel, 1995, 243.

41 Genç, 1999, 6; Çoruhlu, 2002, 186-187.

42 Ögel, 1993, 101, 571; Çoruhlu, 2002, 190-191.

43 Genç, 1999, 9-6; Ersoy, 2000, 52.

44 Çoruhlu, 2002, 191-193.

45 Ersoy, 2000, 58-59; Genç, 1999, 27-36.
} 
Gerek Şeref Salonu'nda gerekse Mezar Odası'nda siyah mermer daha çok motifleri belirleyici ya da sınırlayıcı olarak kullanılmıştır. Türk mitolojisinde toprak rengi olarak kullanılan kara, aynı zamanda kuzeyin de sembolüdür. ${ }^{46}$ Bütün renklerin başlangıcı olan siyah, Türkler için şiddet ve güç yoğunluğu vurgulamada, yas, ölüm ifadelerinde kullanılmaktadır. ${ }^{47}$

Anıtkabir'in iki önemli mekânında kullanılan mermerler renklerine göre ele alındığında tutulan yasın gücünü, ölümü, yok olmayı, cenneti hatırlatmanın dışında Şeref Salonu'nda ve Mezar Odası'ndaki renklerle hâkimiyet, iktidar, güç ve umut kavramlarının ağırlığı hissedilmektedir. Öyle ki Türk dünyasında yeryüzünü tanımlayan yönleri temsil eden bütün renkler bu mekânlardadır. Şeref Salonu'nun duvarlarını kaplayan yeşil ya da gök rengi doğuyu, Türklerin geldiği, gelirken biriktirdiği kültür değerlerini, Türk medeniyetini simgelerken; batıyı simgeleyen beyaz mermerlerle kaplanmış Atatürk'ün lahdinin bulunduğu eyvan Türklerin batıya akışını hatırlatmaktadır.

Şeref Salonu'nda dikkati çeken bir başka unsur da kırmızı ağırlıklı zeminde daha çok Türk halı ve kilimlerinden alınmış motiflerin ve düzenlemenin etkisiyle halı izlenimi veren mermer döşemedir. Bu uygulamada halı etkisi ile mekâna verilecek sıcaklığın dışında, halının, Türk'ün dünya medeniyetine önemli armağanlarından biri olduğunun düşünüldüğü inancındayız. Türk kültüründe halı sadece yaygı olarak değil; mesela Göktürklerde tahta çıkma törenlerinde Türk hakanlarını, göğe çıkma törenlerinde kamları içine koyup kaldırmada da kullanılmıştır. Ayrıca halı ve kilimlerde yer alan nakışların bir dile sahip olduğu da bilinmektedir. ${ }^{48}$ Şeref Salonu'nda en fazla karşımıza çıkan motiflerden biri koçboynuzudur. Türk kültür hayatında koç ya da koyun heykeli, resmi veya piktogram yapma geleneğini totem ya da tamga olarak kabul edenlerin yanı sıra kurban geleneğinin devamı olduğunu belirtenler de vardır. Bolluk, bereket, kuvvet sembolü olarak da bilinen koç, yüksek rütbeli alp mezarlarında bulunmaktadır. Koruyucu ruh inancı ile pek çok eşyanın üzerinde muska, nazarlık gibi de yer alan koç motifinin dışında, koç heykelleri de yiğitler veya önemli şahıslar için dikilmekteydi. ${ }^{49} \mathrm{Bu}$ da Atatürk'ün mezar anıtında koçboynuzu şeklindeki motiflerin neden sıklıkla kullanıldığını açıklamaktadır. ${ }^{50}$

Gücün kuvvetin ve yiğitliğin sembolü olarak görülen koç figürüne Türklerin tarih sahnesindeki ilk eserlerinden itibaren rastlanmakta, MÖ IV.-III. yy’a tarihlenen Hun Dönemi'ne ait Pazırık Halısı'nın kenarsuyundaki atların üzerindeki saçaklı eyer örtülerinde

46 Genç, 1999, 46-50.

47 Genç, 1999, 42; Ersoy, 2000, 65.

48 Ögel, 1995, 166-67.

49 Çay, 1983, 61; Çay, 1990, 181-183.

50 Anadolu'nun pek çok yerinde "koç”, "koçak” kelimeleri yiğit anlamında kullanılmaktadır. Kars ve yöresinde ise kahramanlık, yiğitlik türkülerine "koçaklama" denilmektedir. (Çay, 1983, 90.) 
koçboynuzu motifleri görülmektedir. ${ }^{51}$ Yine Pazırık Kurganları'nda (MÖ III.yy.) ahşap at koşum takımlarında da koçboynuzlarına rastlanmaktadır. ${ }^{52}$ Amuderya'nın Aral Gölü'ne döküldüğü bölgede, MÖ I. - MS VII. yy. Toprakkale Sarayı'ndaki alp heykelleri koç başlı kaidelere sahiptir. ${ }^{53}$ Göktürk Dönemi'ne ait Kültigin (732) ve Bilge Kağan mezar külliyelerinde (735), girişlerin iki yanında koç heykellerinin varlığg bilinmektedir. Türkler özellikle Azerbaycan ve Doğu Anadolu Bölgesi'ndeki koç ya da koyun heykeli şeklindeki mezar taşları ile bu geleneklerini yüzyıllar boyunca sürdürmüşlerdir. ${ }^{54}$

Yine Şeref Salonu'ndaki süslemeler arasında bir başka motif olan ve yaba da denilen ok-yay, çok eski devirlerden itibaren Türk sanatındaki yerini almıştır. Karasuk (MÖ 1300-800) dönemine ait bir dikilitaş Türk dönemine has büyük bir yay ve bir küçük yay ile oktan oluşmuş tamgaya sahiptir. ${ }^{55}$ Hun Dönemi’ne veya Göktürklere ait kurgan buluntularında ok ve yaylara da rastlanmaktadır. ${ }^{56}$ İslam öncesi dönemlerde Türkler hem mezarlara ölen kişi ile ilgili olarak ok ve yayları koymuşlar, hem de bunları çeşitli malzemeler üzerine biçimlendirmişlerdir. Yay resmi, Orhun ve Yenisey alfabelerinde "Y" harfine işaret ederken, ok ise " $o k$ ' $k u, u k$ " gibi telaffuz edilmektedir. Türk askeri ve kabile teşkilatından bahsedilirken Orhun alfabelerinde boy yerine ok kullanılması bu işaretin etnik bir anlam taşımasının yanında harp silahı manasında da kullanıldığına işaret etmektedir. $^{57}$

Aslında iki-üç dişli veya çok dişli yaba Hinduizm-Brahmanizm dininde yıkıcı tanrı Şiva'nın sembolü olarak ifade edilmekteyse de Türk dünyasında damga veya savaşçılı̆̆ın - yiğitliğin sembolü olarak anlam kazandığı anlaşılmaktadır. Türklere ait dokumalarda yaygın olarak yer alan yaba ya da ok-yay motifi Abbasilerin Türkler için yaptırdığı Samarra’da, Karahanlı, Selçuklu yapılarındaki süslemeler arasında da görülmektedir. ${ }^{58}$

Tuğrul Bey’in armasında (1037-1063), Selçuklu hükümdarlarının mezarlarında, sikkelerinde, ok-yay damgalı tuğra kazılmış şekiller yer almıştır. Ayrıca ok ve yay motif ya da damgalarına Kırım'da Hazar Türklerinin mezar taşlarında, ${ }^{59}$ Karakoyunlu ve Akkoyunlulara ait koç ve at şeklindeki mezar taşları üzerinde rastlanmaktadır. ${ }^{60}$ Saraybosna ve çevresindeki Osmanlı Dönemi'ne ait mezar taşlarında da ok ve yay

51 Kırzıoğlu, 2001, 71.

52 Diyarbekirli, 1969, 140.

53 Çay, 1990, 31.

54 Karamağaralı, 1992, 38; Pektaş, 2001, 123.

55 Esin, 2003, Res. 76, Res. 78.

56 Ögel, 1991, 75, 144.

57 Karamağaralı, 1980, 16.

58 Kırzıoğlu, 2001, 207.

59 Kırzıoğlu, 2001, 173.

60 Diyarbekirli, 1969, 189-190. 
kabartmaları karşımıza çıkmaktadır. ${ }^{61}$ Başta Osmanlı Devleti’nin kurucusu Kayı Boyu'nda olmak üzere çeşitli Türk topluluklarının damga olarak kullandıkları ok-yay motifinin diğer taraftan savaşçılık, yiğitlik sembolü olarak belki de koruma amaçlı Türk mezar geleneğinde fazlasıyla yer alan bir motif olduğu anlaşılmaktadır. Her şeyin ötesinde büyük bir askeri deha olan Atatürk'ün kabrinde bu motife yer verilmiş olması köklü bir Türk geleneğinin devamı niteliğindedir.

Anıtkabir'deki en önemli mekân tartışmasız Atatürk'ün Mezar Odası'dır. Şeref Salonu'nun alt katında, lahdin hizasına denk gelen sekizgen gövde üzerine piramidal külahla örtülü bu bölümün ve süslemelerinin üzerinde durulmuştu. Bu mekânda gövde, piramidal örtü, örtünün ortasındaki 1şıklık ve bu 1şıklıktan örtünün her bir köşesine yayılan altın mozaik ışınlar, zemindeki sandukayı sınırlayan alan sekiz köşelidir. Böylece dikkatimizi çeken sekizgen aslında kare ile daire arasında bir görünüşe sahiptir. Sekizgen, dünyayı (yeri) sembolize eden kare ile göğü temsil eden kubbe arasında bağlantıyı, geçiş evresini de simgelemekte ve ezoterik ekole göre 8, 7' den sonra geldiğinden diriliş, yeniden başlama ve şekil değiştirmenin simgesi olarak değerlendirilmektedir. ${ }^{62}$ Yakutlarda da Gök Tanrı'nın ilk şaman için evinin önüne diktiği sekiz dallı ağacın sonsuza kadar yaşayacağı düşüncesi hâkimdir ve her gün yenilenen dünya onlara göre sekiz köşelidir. ${ }^{63}$ Sekiz uçlu geometri, yenilenmenin, ölümsüzlüğün sembolü olarak ifade edilmektedir. ${ }^{64}$ Diğer taraftan, Hz. Muhammed'in bir hadisinde cennetin sekiz kapisı olduğunu söylediğinden bahsedilir. Burada sekiz köşeli biçimlerle Atatürk için bu dünyadan ahirete göçü, ölümsüzlüğü, mekânının cennet olması dileği ifade edilmek istenmiştir. Atatürk'ün Mezar Odası'nı örten piramidal örtü, merkezde sekizgen bir 1şıklıktan yayılan 1şınlarla aydınlanmaktadır. Kur'an-1 Kerim'in Hakka Suresi'nde kıyametten, göğün yarılmasından bahsedilirken 17. Ayet'te "Melekler de onun kenarlarındadır. O gün Rabbinin tahtını, üstlerinde sekiz melek taşır.” ve Nur Suresi 35. Ayet’te “Allah göklerin ve yerin nurudur." denilmektedir. Yani bu Mezar Odası'nda sekizgen 1şıklıktan süzülen Allah'ın nurunu tasvir ettiğini düşündüğümüz 1şınlar, Atatürk'ün, cennet olmasını istediğimiz ebedî mekânını aydınlatmaktadır.

Mezar Odası'nda, Atatürk'ün, zeminin ortasındaki lahdinin bulunduğu sekizgen alanın dışında yer alan sekiz dörtgen bölümün her birinin ortasında kırmızı zemin üzerine beyaz çapraz şeritler bulunduğundan ve beyaz çapraz motiflerin üst ve alt açıklıklarının siyah mermerle dolgulandığından bahsedilmişti. Hun Dönemi'ne ait kurganlardan çıkan, başta Pazırık Halısı olmak üzere, eyer örtüsü gibi pek çok dokumanın üstünde kare alan içersinde çapraz motifler dikkat çekmektedir. Uygur Dönemi'ne ait bir kitap cildinde, ${ }^{65}$ Bezeklik tapınaklarındaki duvar resimlerinde kare içersinde çapraz çizgili

61 Karamağaralı, 1980, 14.

62 Ersoy, 2000, 36.

63 Ögel, 1993, 93.

64 Ateş, 1996, 90.

65 Esin, 1978, Levha LXXXVII/d 
motiflere rastlanmaktadır. ${ }^{66}$ Talas Vadisi'ndeki kazılarda bulunan X.-XII. yy’a ait bir evin süslemeleri arasında, kareler içersinde merkezinde dört yapraklı çiçekleri olan çapraz şeritler görülmektedir. ${ }^{67}$ Büyük Selçuklulara ait sekizgen gövdeli Harrekan Kümbetlerinden doğudakinin (1067-68) cephelerinden biri, eşkenar dörtgenlerle çevrelenmiş çapraz motiflere sahiptir. ${ }^{68}$ Büyük Selçuklulara ait Ribat-1 Şerif' in (1114-15) mescit kısmındaki trompta çapraz şekiller bulunmaktadır. ${ }^{69}$ Ayrıca Orhun Alfabesi'nde "d” sesini veren çapraz şekil Kızık veya Avşar damgası olarak da kullanılmıştır. Konya - Seydişehir bölgesinde görülen mezar taşlarındaki çapraz işaretleri, ${ }^{70}$ Erzincan'ın Eşmepınar köyündeki bazı mezarlarda da tespit edilmiştir. ${ }^{71}$ Ayrıca XV. yy.'a ait bazı Timurlu yapılarında da çapraz biçimli motifi ya da damgayı görmekteyiz. ${ }^{72}$ Bunlardan biri olan Timur'un türbesi Gur-i Mir'de (1405), cepheleri ve pencereleri, eşkenar dörtgenlerin önünde ve arkasında çaprazlar oluşturarak ilerleyen kenarsuları sınırlamaktadır. ${ }^{73}$

Çapraz diye tanımladığımız, birbirini verev olarak kesen iki çizgi aslında ellerini yukarıya kaldırmış bir insana da işaret etmektedir. Bu işaret tıpkı Mevlevilerde olduğu gibi Allah'a yakarışı, teslimiyeti de hatırlatmaktadır. Semâzenin kollarının çapraz bağlı olarak durması Allah'ın birliğini ifade etmektedir. Atatürk'ün Mezar Odası'nın zeminindeki çapraz şeklin üst ve alt açıklıklarında yer alan üçgenler sağlamlığı, duruluğu ve bir yükselişi, tanrı katına yükselişi yansıtmakta, şematik olarak insan kalbini de simgelemektedir. ${ }^{74}$ Burada bu motifle bir taraftan hayatın sonu, maddi hayatın sona erişi; diğer taraftan manevi hayatın başlangıcı sembolize edilmektedir.

Anıtkabir'in, Şeref Salonu ve Mezar Odası'nın dışında, renkli taşların bir motif oluşturacak şekilde bir araya geldiği bir başka bölümü de Tören Alanı'dır. Bu alanın merkezinde renkli taşlar büyük bir hall, daha da çok bir kilim meydana getirmiştir. Ortadaki bu büyük kilimin dışında daha küçük boyuttaki kilimler alanı kaplamaktadır. Bunlarda da ok-yay, çapraz şeritli motiflerden başka kilimlerin göbeklerinde eşkenar dörtgenlere de yer verilmiştir. Anıtkabir'dekilere benzer nitelikte eşkenar dörtgen şeklindeki düzenlemeler, sırlı ve sırsız tuğlalarla adeta kilimlerdeki düzeni yansıtırcasına Karahanlı, Büyük Selçuklu, Anadolu Selçuklu yapılarında da görülmektedir. ${ }^{75}$ Tören Alanı'ndan

66 Esin, 2004, 133, Res. 208.

67 Cezar, 1977, 49.

68 Tuncer, $1986,31$.

69 Cezar, 1977, 207.

70 Karamağaralı, 1980, 7.

71 Çal, 2007, 132, 152.

72 Soustiel vd., 2003, 203.

73 Aslanapa, 1996, 277.

74 Ersoy, 2000, 80-85.

75 Karahanlı dönemine ait Talhatan Baba Camii'nin (XI. yy. sonu - XII. yy başları) cephesinde (Cezar, 1977, 35.); Özkent - Celaleddin Hüseyin Türbesi’nde (1152) taç kapıyı dışta çevreleyen kenarsuyunda (Aslanapa, 1996, 220.); Büyük Selçuklulara ait Demavend Kümbeti’nin 
Mozole'ye götüren merdivenlerin ortasına yerleştirilen beyaz mermer ve hitabet kürsüsünde Atatürk'ün "Hâkimiyet kayıtsız şartsız milletindir." sözünün yazılı olduğu alan, helezon şeklindeki oymalarla çevrelenmişlerdir. Neolitik Çağ' da ortaya çıkmış olan bu motif yeniden doğuşu simgelemektedir. ${ }^{76}$ Aynı zamanda üretim, bereket simgesi olan helezonun; doğumu olduğu kadar, ölümden sonra ruhun sonsuza doğru yapacağı seyahatte çizdiği yolu temsil ettiği de ileri sürülmektedir. ${ }^{77}$ Hun Dönemi'nden başlayarak Türk sanatının hemen her döneminde çeşitli eserlerde yer alan helezon şeklindeki motifler ${ }^{78}$ böylece Anıtkabir'de, Atatürk'ün Türk Milleti'ne en büyük armağanlarından biri olan "hâkimiyet" unsurunu ölümsüzleştirmektedir.

\section{Sonuç}

Atatürk'ün 10 Kasım 1953 Perşembe günü Etnografya Müzesi’nden alınan naşının, Anıtkabir'de hazırlanan mezarında her ilden getirilen vatan toprağına gömüldüğü ve bu toprağa dökülen iki teneke sudan birinin Çanakkale Boğazı'ndan diğerinin ise İstanbul Boğazı'ndan getirildiği, ${ }^{79}$ böylece gömülme şeklinde de sembollere yer verildiği dikkate alındığında; Anıtkabir'de var olan bütün unsurların yapının mimarları ve onlara çalışmalarında yardım eden komisyon üyeleri tarafından ayrıntılı düşünülerek titizlikle seçildiğine inancımız artmaktadır. Aslında kendisi başlı başına bir sembol olan Anıtkabir'in çalışmamıza konu teşkil eden renkli taşlarında kullanılan ve Türk tarihinin derinliklerinden gelen motiflerinde, seçimin rastgele olmadığ 1 açıktır. Anıtkabir' in, başta tasarımı olmak üzere, heykel, kabartma ve yapıdaki yazıları gibi, söz konusu edilen motiflerinin de, "süsleme" ötesinde bir anlam ifade ettiği, özenle seçildiği görüşündeyiz. Türklerin İslam öncesinde de, Müslüman olduktan sonra da küçük sanatlarında ve mimarilerinde kullandıkları bu motif ve damgalar Anıtkabir'de çoğu zaman aynen, bazen de asıllarına sadık kalınarak yeni düzenlemelerle karşımıza çıkmaktadır.

Özellikle süslemelerinde yer alan motifleriyle Türk sanatının vurgusu artırılmış Anıtkabir'i Türk Milleti'nin önemli sembollerinden biri haline getiren her şeyden öte mezarını barındırdı̆̆ı Atatürk'ün varlığıdır.

gövdesinde (XI. yy’ın ikinci yarısı) (Cezar, 1977, 331.); Gülpayegan Camii (1108-1118) minaresinin gövdesinde (Cezar, 1977, 359.); Tarikhane Camii minaresinde (Cezar, 1977, 366.); Anadolu Selçuklu dönemine ait Pınarbaşı - Melik Gazi Türbesi'nin (XII.yy sonları) giriş cephesinde (Önkal, 1996, Res. 354); Malatya Ulu Camii avlu revakındaki kemer yüzeylerinde ve Konya Gömeç Hatun Türbesinin (XIII. yy sonu - XIV. yy başı) eyvan kemerindeki çini süsleme kalıntıları eşkenar dörtgenlerden gelişen hal1-kilim bezemelerini hatırlatır. (Önkal, 1996, 526.)

76 Eberhard, 2000, 140.

77 Ersoy, 2000, 344.

78 Helezon şeklinde kıvrımlara sahip motiflere Hun döneminden itibaren rastlanmaktadır (Diyarbekirli, 1969, 112-204.) Türkistan'da Çıkan Köl Mağara 5'de ilk Uygur Dönemine ait (VIII. yy.) bir duvar resminde (Esin, 2003, Res. 229.) yine bir Uygur kağanı için dikilen IX. yy.'a ait taş anıtın kaidesinde helezon kıvrımlar görülmektedir. (Esin, 2004, Res. 252.)

79 Şapolyo, 1972, 115. 


\section{KAYNAKÇA}

Alpagut Karsl1, Leyla (1999), Mimar Clemens Holzmeister ve III. T.B.M.M. Binast, Hacettepe Üniv., Sosyal Bilimler Enstitüsü, Yüksek Lisans Tezi, Ankara.

Arda, Orhan (1961-62), Anıt Kabir, Mimarlık ve Sanat, C.1, S. 4-5.

Aslanapa, Oktay (1996), Türk Cumhuriyetleri Mimarlık Abideleri, Ankara.

Aslanoğlu, İnci (1994), Ankara’da Yirmi Y1lın Mimarlık Değerlendirmesi: 1940-1960. Enis Batur (Ed.), Ankara Ankara, 227-242, İstanbul: YKY.

Aslanoğlu, İnci (2000), 1928-1946 Döneminde Ankara'da Yapılan Resmi Yapıların Mimarisinin Değerlendirilmesi. Ayş1 Tükel Yavuz (Derleyen), Tarih İçinde Ankara, 271-286, Ankara: ODTÜ - Ankaralılar Vakfi.

Ateş, Mehmet (1996), Mitolojiler Semboller ve Halılar, İstanbul.

Azak, Gürbüz (1993), 3000 Türk Motifi ,İstanbul.

Batur, Afife (2001), Anıtkabir, Büyük Ölümün Patetik Yontusu, Ozan Sağdıç, Anıtkabir,Anıtkabir, Ankara

Cezar, Mustafa (1977), Anadolu Öncesi Türklerde Şehir ve Mimarlı, İstanbul.

Çakmakoğlu, Alev (1983), İstanbul Türk Mimarisinde Renkli Taş Süslemeler, Türkiyemiz, Y11:14, S. 40, 1-12. (İstanbul)

Çakmakoğlu, Alev (1989), Süleymaniye Camii'nin Renkli Dünyası, Kültür ve Sanat Dergisi, Y11: 1, S. 3, 29-33. (Ankara)

Çal, Halit (2007), Erzincan Çayırlı Eşmepınar Köyü Mezar Taşları, Sanat Tarihi Araştırmalart - Prof. Dr. Haşim Karpuz'a Armağan, 125-154. (Konya)

Çay, M. Abdulhaluk (1983), Anadolu'da Türk Damgası, Koç Heykel Mezar Taşları ve Türklerde Koç-Koyun Meselesi, Ankara.

Çay, M. Abdulhaluk (1990), Türk Milli Kültürü'nde Hayvan Motifleri (I), Ankara.

Çoruhlu, Yaşar (2002), Türk Mitolojisinin Anahatları, İstanbul.

Diez, Ernst - Aslanapa, Oktay - Koman, M. Mesut (1950), Karaman Devri Sanatı, İstanbul.

Diyarbekirli, Nejat (1969), Türk Sanatının Kaynaklarına Doğru, Türk Sanatı Tarihi Araştırma ve İncelemeleri, 112-204. İstanbul.

Eberhard, Wolfram (2000), Çin Simgeleri Sözlüğü, İstanbul.

Erdoğdu, Şeref (1965), Ankaram, Ankara.

Ersoy, Necmettin (2000), Semboller ve Yorumları, Bölüm I-II, İstanbul.

Eser, Erdal (2000 ), 11-14. Yüzyıllarda Anadolu Suriye Sanat İlişkileri, Hacettepe Üniv., Sosyal Bilimler Enstitüsü, Yayınlanmamış Doktora Tezi, Ankara.

Esin, Emel (1978), İslamiyet'ten Önceki Türk Kültür Tarihi ve İslam 'a Giriş, İstanbul.

Esin, Emel (2003), Orta Asya'dan Osmanlı'ya Türk Sanatında İkonografik Motifler, İstanbul.

Esin, Emel (2004), Türk Sanatında İkonografik Motifler, İstanbul. 
Evliyagil, Nejdet (1947), Anıt-Kabir İnşaatı 3 Seneden Evvel İkmal Edilemeyecek, Cumhuriyet Gazetesi, 27 Kasim 1947.

Evliyagil, Nejdet (1988), Atatürk ve Anitkabir, Ankara.

Genç, Reşat (1999), Türk Inanışları ile Milli Geleneklerinde Renkler ve Sarı, Kırmızı, Yeşil, Ankara.

Gülekli, Can (1973), Anttkabir Rehberi, Ankara.

İnan, Afet (1972), Atatürk'ün Biyografisi, Etibank Bülteni Atatürk Özel Saylsl, 43-57. Ankara.

Karamağaralı, Beyhan (1980), Türk Damgalarının Devamlılı̆̆ı Hakkında, Türk Dünyası Araştırmaları, Y11: 2, C. 3, S. 9, SAYFA? İstanbul.

Karamağaralı, Beyhan (1992), Ahlat Mezar Taşları, Ankara.

Kırzıoğlu Görgünay, Neriman (2001), Altaylardan Tuna Boyuna Türk Dünyasında Ortak Yanışlar (Motifler), Ankara.

Kortan, Enis (2005), Anıtkabir Projesi Üzerine,Yapl, S. 283, 57-61.

Ögel, Bahaeddin (1991), Türk Kültür Tarihi, Ankara.

Ögel, Bahaeddin (1993), Türk Mitolojisi, I. Cilt, Ankara.

Ögel, Bahaeddin (1995), Türk Mitolojisi, II. Cilt, Ankara.

Öney, Gönül (1970), Anadolu Selçuklu Mimarisinde Antik Devir Malzemesi, Anadolu, XII, 27-38. (Ankara)

Önge, Y1lmaz (1997), Türk Mimarisinde Anadolu Selçuklu ve Osmanlı Dönemi Su Yapıları, Ankara.

Önkal, Hakkı (1996), Anadolu Selçuklu Türbeleri, Ankara.

Pektaş, Kadir (2001), Bitlis Tarihi Mezarlıkları ve Mezar Taşları, Ankara.

Soustiel, J. - Porter, Y. (2003), Tombs of Paradise, Saint-Rémy-en-1'Eau : Monelle Hayot.

Sözen, Metin - Tapan, Mete (1973), 50 Yılın Türk Mimarisi, İstanbul.

Sözen, Metin (1984), Cumhuriyet Dönemi Türk Mimarisi, Ankara.

Şapolyo, E. Behnan (1972), Atatürk Anıtkabir'de, Etibank Bülteni Atatürk Özel Sayısı, 111-115, Ankara.

Tekin, Serdar (2005), Atatürk ve Anıtkabir, Hacettepe Üniv. Atatürk İlkeleri ve İnkılap Tarihi Enstitüsü, Yüksek Lisans Tezi, Ankara.

Tuncer, O. Cezmi (1986), Anadolu Kümbetleri, C. I., Ankara.

T. C. Genel Kurmay Başkanlığı (2001), Anıtkabir Tarihçesi, Ankara.

Yavi, Ersal (1996), Anadolu Mermer Uygarlı̆̆l, İzmir.

Yetkin, Şerare (1972), Anadolu'da Türk Çini Sanatının Gelişmesi, İstanbul.

Yıldırım, Yavuz (1994), 1923-1940 Arası Ankara'da Mimari. Enis Batur (Ed.), Ankara Ankara, 201-208, İstanbul: YKY. 